\title{
Revisiting the relationship between Atlantic dust and tropical cyclone activity using aerosol optical depth reanalyses: 2003-2018
}

\author{
Peng Xian $^{1, \star}$, Philip J. Klotzbach ${ }^{2, \star}$, Jason P. Dunion ${ }^{3}$, Matthew A. Janiga ${ }^{1}$, Jeffrey S. Reid ${ }^{1}$, Peter R. Colarco ${ }^{4}$, and \\ Zak Kipling ${ }^{5}$ \\ ${ }^{1}$ Naval Research Laboratory, Monterey, CA, USA \\ ${ }^{2}$ Department of Atmospheric Science, Colorado State University, Fort Collins, CO, USA \\ ${ }^{3}$ Cooperative Institute for Marine and Atmospheric Studies, University of Miami, and NOAA/Atlantic Oceanographic and \\ Meteorological Laboratory/Hurricane Research Division, Miami, Florida, USA \\ ${ }^{4}$ NASA Goddard Space Flight Center, Greenbelt, MD, USA \\ ${ }^{5}$ European Centre for Medium-Range Weather Forecasts, Reading, UK \\ * These authors contributed equally to this work.
}

Correspondence: Peng Xian (peng.xian@nrlmry.navy.mil)

Received: 31 March 2020 - Discussion started: 15 June 2020

Revised: 13 September 2020 - Accepted: 8 October 2020 - Published: 11 December 2020

\begin{abstract}
Previous studies have noted a relationship between African dust and Atlantic tropical cyclone (TC) activity. However, due to the limitations of past dust analyses, the strength of this relationship remains uncertain. The emergence of aerosol reanalyses, including the Navy Aerosol Analysis and Prediction System (NAAPS) aerosol optical depth (AOD) reanalysis, NASA Modern-Era Retrospective analysis for Research and Applications, Version 2 (MERRA2), and ECMWF Copernicus Atmosphere Monitoring Service reanalysis (CAMSRA), enables an investigation of the relationship between African dust and TC activity over the tropical Atlantic and Caribbean in a consistent temporal and spatial manner for 2003-2018. Although June-July-August (JJA) $550 \mathrm{~nm}$ dust AOD (DAOD) from all three reanalysis products correlates significantly over the tropical Atlantic and Caribbean, the difference in DAOD magnitude between products can be as large as $60 \%$ over the Caribbean and $20 \%$ over the tropical North Atlantic. Based on the three individual reanalyses, we have created an aerosol multireanalysis consensus (MRC). The MRC presents overall better root mean square error over the tropical Atlantic and Caribbean compared to individual reanalyses when verified with ground-based AErosol RObotic NETwork (AERONET) AOD measurements. Each of the three individual reanalyses
\end{abstract}

and the MRC have significant negative correlations between JJA Caribbean DAOD and seasonal Atlantic accumulated cyclone energy (ACE), while the correlation between JJA tropical North Atlantic DAOD and seasonal ACE is weaker. Possible reasons for this regional difference are provided. A composite analysis of 3 high-JJA-Caribbean-DAOD years versus 3 low-JJA-Caribbean-DAOD years reveals large differences in overall Atlantic TC activity. We also show that JJA Caribbean DAOD is significantly correlated with largescale fields associated with variability in interannual Atlantic TC activity including zonal wind shear, mid-level moisture, and sea surface temperature (SST), as well as the El NiñoSouthern Oscillation (ENSO) and the Atlantic Meridional Mode (AMM), implying confounding effects of these factors on the dust-TC relationship. We find that seasonal Atlantic DAOD and the AMM, the leading mode of coupled Atlantic variability, are inversely related and intertwined in the dustTC relationship. Overall, DAOD in both the tropical Atlantic and Caribbean is negatively correlated with Atlantic hurricane frequency and intensity, with stronger correlations in the Caribbean than farther east in the tropical North Atlantic. 


\section{Introduction}

Saharan dust particles can affect weather and climate through both direct and indirect radiative and cloud processes, notably in association with boreal summer Saharan Air Layer (SAL) outbreaks. The SAL is a layer of hot and dry air that forms over continental West Africa and is then advected over the low-level moist marine boundary layer of the tropical Atlantic (Carlson and Prospero, 1972). The SAL is often associated with the African easterly jet (AEJ), which can enhance vertical wind shear. Despite numerous observational and modeling studies that have examined the relationships between these aspects of the SAL and Atlantic tropical cyclone (TC) activity, there are conflicting findings as to whether dust acts to generally inhibit or enhance tropical cyclogenesis and intensification. Some studies suggest negative impacts of the SAL's dust-laden dry air and the AEJ on TC activity (e.g., Dunion and Velden, 2004; Lau and Kim, 2007; Jones et al., 2007; Sun et al., 2008; Pratt and Evans, 2008), while others have focused exclusively on the dust particles themselves and have found a negative influence on TCs (e.g., Evan et al., 2006a; Rosenfield et al., 2007; Strong et al., 2018; Reed et al., 2019). Other studies have suggested little impact of the SAL on TCs (e.g., Braun, 2010; Sippel et al., 2011; Braun et al., 2013), while others have posited a positive impact of dust on TCs through cloud-microphysical processes (e.g., Jenkins et al. 2008). Finally, others have suggested that there are contrasting influences through different mechanisms and for different TCs (Karyampudi and Pierce, 2002; Bretl et al. 2015; Pan et al., 2018), highlighting the complexity of the dust-TC interaction.

African dust impacts the North Atlantic throughout the year, with its summer peak season (May-August) overlapping and leading the peak of the Atlantic hurricane season (August-October; Fig. S1). As African dust outbreaks during the summer are often associated with the SAL, airborne dust has often been used as an indicator for the SAL (Dunion and Velden, 2004; Dunion, 2011; Tsamalis et al., 2013), although early season cases where the majority of the dust existed in the marine boundary layer below the trade wind inversion instead of staying aloft were also found (Reid et al., 2003). Saharan dust and the SAL are frequently observed throughout the Caribbean and as far west as Central America and the North American continent during the boreal summer (e.g., Prospero, 1999; Reid et al., 2003; Dunion and Velden 2004; Nowottnick et al., 2011; Kuciauskas et al., 2018). Airborne dust associated with the SAL often extends to $5.5 \mathrm{~km}$ $(500 \mathrm{hPa})$ off of western Africa and becomes thinner as its top lowers and its base rises as it is advected westward, shrinking to below $2 \mathrm{~km}$ in the Caribbean and in the Gulf of Mexico (Tsamalis et al., 2013). In some strong SAL cases, however, the top of the dust layer can reach $6 \mathrm{~km}$ (Reid et al., 2003; Colarco et al., 2003). During their trans-Atlantic transport, dust aerosols are from time to time observed to interact with TCs, as seen in satellite imagery (Fig. 1).

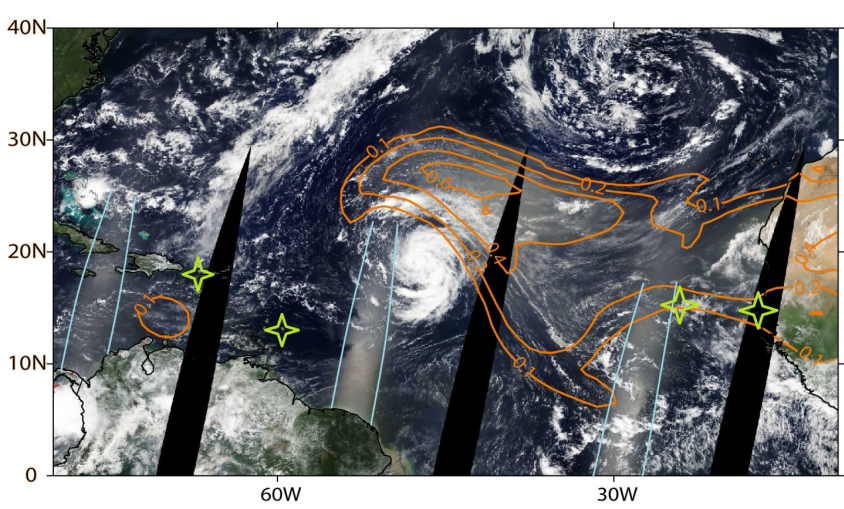

Figure 1. True-color Terra Moderate Resolution Imaging Spectroradiometer (MODIS) satellite imagery composited on 12 September 2012 and overlaid with NAAPS-RA $550 \mathrm{~nm}$ dust aerosol optical depth (DAOD, an approximate measure of total atmospheric column of dust aerosol mass, unitless) isopleths, showing Hurricane Nadine's interaction with the SAL. Hurricane Nadine is located in the middle of the image. African dust appears as a light transparent brown haze in between the African coast and Hurricane Nadine, as well as wrapping around the northern periphery of the storm. Note that areas of sunglint (narrow regions between the light blue curves) are similar in color to the dust aerosols but have the same orientation as the satellite orbits and are located approximately midway between satellite coverage gaps (black regions oriented south-southwest to north-northeast). Satellite imagery courtesy of the MODIS flying on NASA's Terra satellite and available from https://worldview.earthdata.nasa.gov/ (last access: 25 November 2020). The stars in light green represent four sites used for validation purposes, including Dakar, Cabo Verde, Ragged Point, and La Parguera in order from east to west.

African dust and its associated SAL has been hypothesized to impact TCs through a variety of mechanisms. Through scattering and absorbing sunlight, dust reduces solar radiation reaching the surface, thus cooling sea surface temperatures (SSTs; e.g., Miller and Tegen, 1998; Lau and Kim, 2007; Evan et al., 2009). Lower SSTs provide TCs with less energy to initiate, develop, and maintain strength. Through additional radiative heating of the dusty layer, mineral dust is also suggested to impact the structure, location, and energetics of the AEJ (Tompkins et al., 2005; Wilcox et al., 2010; Reale et al., 2011) and African easterly wave (AEW) activity (Karyampudi and Carlson, 1988; Reale et al., 2009; Nathan et al., 2017; Jones et al., 2004; Ma et al., 2012; Grogan et al., 2016, 2017; Bercos-Hickey et al., 2017), thus having implications for tropical cyclogenesis. From a thermodynamic point of view, Dunion and Velden (2004) have proposed that the dust-carrying SAL outbreaks could inhibit TC formation and development in the North Atlantic through three primary mechanisms, including dry air intrusion into the storm, enhancement of the local vertical wind shear associated with the enhanced AEJ, and stabilization of the environment due 
to radiative heating of the dust layer above the marine boundary layer.

Dust particles can also act as cloud condensation nuclei (Twohy et al., 2009; Karydis et al., 2011) and ice nuclei (DeMott et al., 2003; Sassen et al., 2003) and affect cloud microphysics, weakening or strengthening convection depending on the environment (Khain, 2009). Focusing specifically on TCs, there is not a consistent conclusion among studies on whether the microphysical impacts of dust weaken or strengthen TCs (Jenkins et al., 2008; Rosenfeld et al., 2007; Zhang et al., 2007, 2009; Herbener et al., 2014; Nowottnick et al., 2018).

While dust aerosols can affect TC formation and development through radiative and cloud-microphysical impacts, TCs can in turn impact dust aerosol spatial distributions through wet removal and dynamic flow (Herbener et al., 2016). AEWs, serving as seeding disturbances for TCs (Landsea, 1993), are shown to contribute to dust emission and transport (e.g., Westphal et al., 1987; Jones et al., 2003; Knippertz and Todd, 2010). Climate variability that affects TC activity can also impact African dust emission and transport over the North Atlantic and Caribbean. For example, the El Niño-Southern Oscillation (ENSO) was found to affect the emission and transport of African dust as well (Prospero and Lamb, 2003; DeFlorio et al., 2016), especially during the boreal winter (Prospero and Nees, 1986; Evan et al., 2006b).

How all of these factors interact in the complex climate system and to what extent they can impact TC formation and intensification is still largely unknown. The goal of this study is to explore how the integrated interactions manifest themselves in the relationship between Saharan dust and Atlantic TC activity on seasonal to interannual timescales using state-of-the-art aerosol reanalysis data. This serves as a first step towards further understanding the dust-TC relationship and evaluating the relative importance of different mechanisms. Previous empirical studies on the relationship between African dust and Atlantic TC activity are limited by uneven spatial and temporal sampling by satellite and in situ-based observations. The emergence of several aerosol reanalysis datasets, including the Navy Aerosol Analysis and Prediction System (NAAPS) aerosol optical depth (AOD) reanalysis (NAAPS-RA, Lynch et al., 2016), the Modern-Era Retrospective analysis for Research and Applications, Version 2 (MERRA-2) aerosol reanalysis (Randles et al., 2017), and the Copernicus Atmosphere Monitoring Service reanalysis (CAMSRA) (Inness et al., 2019), allow us to investigate this relationship in a more consistent manner over their joint time period to provide a degree of statistical robustness.

In Sect. 2, an introduction to the aerosol and large-scale environmental data and the analysis methods employed is provided. Section 3 presents the dust AOD (DAOD) climatology, its interannual variability over the Atlantic, and comparisons of the three aerosol reanalyses. This section also evaluates correlations between DAOD and Atlantic TC activity, as well as the relationship between DAOD and large-scale environmental conditions and climate modes. The sensitivity of the results to the definition of the regions, the number of composite years used, and the definition of dust seasons are provided in Sect. 4. A discussion and conclusions are given in Sect. 5.

\section{Data and methods}

\subsection{Methods}

Regardless of the underlying mechanisms, as there are contradicting mechanisms proposed in different studies, the goal of this study is to examine if there is a robust and statistically significant relationship between African dust and Atlantic $\mathrm{TC}$ activity on seasonal to interannual timescales. We also examine if there are confounding factors, for example, meteorological conditions and climate modes, that covary with dust and hence influence TC activity.

We use dust AOD (DAOD) to represent Atlantic dust levels. Three aerosol reanalysis products, and their consensus DAOD, are used in order to increase the fidelity of the analysis result, given that multi-model consensus typically has been shown to have better data quality in prior assessments (Sessions et al., 2015; Xian et al., 2019). Various TC count indices and accumulated cyclone energy (ACE) (Bell et al. 2000), defined in the next section, are utilized to represent TC activity.

The Atlantic Main Development Region (MDR) (e.g., Goldenberg et al., 2001), including the Caribbean (10-20 $\mathrm{N}$, $\left.85-60^{\circ} \mathrm{W}\right)$ and the tropical North Atlantic $\left(10-20^{\circ} \mathrm{N}, 60\right.$ $20^{\circ} \mathrm{W}$ ), are the focus regions for this study (see also Fig. 2 for a spatial representation of the two subregions). Most previous studies of dust impacts on TC activity have focused on the tropical North Atlantic or regions closer to the African continent (e.g., Karyampudi and Pierce, 2002; Bretl et al., 2015; Pan et al., 2018) where DAOD is relatively high. However significant dust pulses can also be transported into the Caribbean. We therefore expand our study area to explore the potential impacts of high levels of dust in the Caribbean on Atlantic TC activity. This allows us to explore regional differences in the dust-TC relationship. Statistical relationships between DAOD and TC activity over the MDR are investigated using the three aerosol reanalyses and multi-reanalysis consensus (MRC). The results obtained herein also help us assess the potential of using DAOD to aid in future Atlantic seasonal hurricane forecasts.

The correlations between variables of interest are based on the Pearson correlation coefficient. Statistical significance is assessed at the $95 \%$ level using a two-tailed Student $t$ test. Correlations $\geq 0.51$ are statistically significant given that a 16-year time period (e.g., 2003-2018) is investigated here. For partial correlation analysis, partial correlations $\geq 0.55$ are statistically significant at the $95 \%$ level with 13 degrees of freedom. The criteria for statistical significance with vari- 


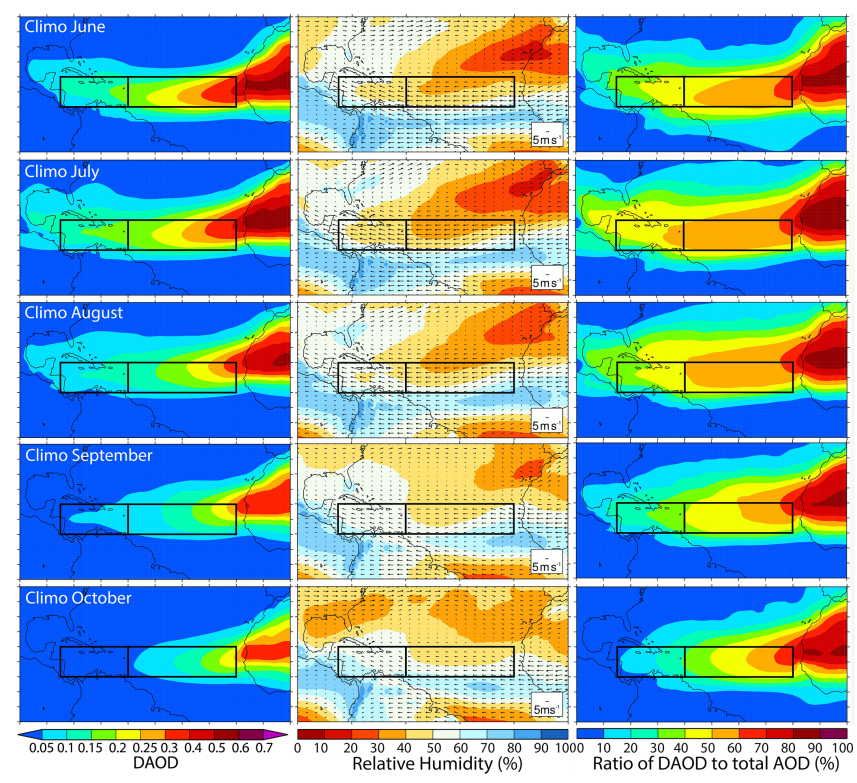

Figure 2. Climatological (2003-2018 average) monthly mean DAOD (left column) and the ratio of DAOD to total AOD (right column) for June-October based on the MRC. The middle column shows the climatological $700 \mathrm{hPa} \mathrm{RH}$ (color shading) and horizontal wind vectors from ERA-Interim. Black boxes denote the MDR, including the Caribbean (left, $10-20^{\circ} \mathrm{N}, 85-60^{\circ} \mathrm{W}$ ) and the tropical North Atlantic (right, 10-20 $\mathrm{N}, 60-20^{\circ} \mathrm{W}$, denoted "TATL").

ous degrees of freedom can also be obtained at https://www. esrl.noaa.gov/psd/data/correlation/significance.html, last access: 25 November 2020.

\subsection{Aerosol data}

A combination of aerosol reanalyses are used to describe the aerosol environment over the tropical North Atlantic and Caribbean. An aerosol multi-reanalysis consensus (MRC) based on three aerosol reanalysis products, including the NAAPS-RA (Lynch et al., 2016) from the US Naval Research Laboratory, MERRA-2 (Randles et al., 2017) from NASA, and CAMSRA (Inness et al., 2019) from ECMWF, are also generated and used. The analysis period is focused on 2003-2018, when all three aerosol reanalyses are available and both Terra and Aqua Moderate Resolution Imaging Spectroradiometer (MODIS) AOD retrievals were assimilated therein.

\subsubsection{NAAPS AOD reanalysis}

The NAAPS-RA product provides $550 \mathrm{~nm}$ speciated AOD at a global scale with $1^{\circ} \times 1^{\circ}$ spatial and 6-hourly temporal resolution for the years 2003-2018 (Lynch et al., 2016). This reanalysis uses a modified version of NAAPS and assimilates quality-controlled AOD retrievals from MODIS on Terra and Aqua and the Multi-angle Imaging SpectroRadiometer (MISR) on Terra (Zhang et al., 2006; Hyer et al.,
2011; Shi et al., 2011). NAAPS characterizes anthropogenic and biogenic fine aerosol species (ABF), dust, sea salt and biomass-burning smoke aerosols. The aerosol source functions were tuned regionally so that a best match between the model coarse- and fine-mode AODs and the Aerosol Robotic Network (AERONET) AODs can be obtained. Other model processes, e.g., deposition, were also tuned to minimize the AOD difference between the model and quality-controlled satellite AOD retrievals. NOAA Climate Prediction Center MORPHing (CMORPH) precipitation derived from satellite observations (Joyce et al., 2004) is used to correct precipitation biases in the tropics for better AOD analyses through wet deposition processes (Xian et al., 2009). The reanalysis captures the decadal AOD trends detected using standalone satellite products in other studies (e.g., Hsu et al., 2012; Zhang et al., 2010), demonstrating the quality of the reanalysis product for climate studies. The NAAPS-RA data for May 2017-November 2018 were generated by assimilating MODIS data-assimilation-quality (DA-quality) AOD only without MISR AOD assimilation because of the unavailability of MISR DA-quality data at the time of this study. The impact of not including MISR is expected to be minor as MISR provides only about $10 \%$ of the total assimilated AOD data. Additionally, differences between monthly mean DA-quality AOD over the MDR region derived using both MODIS and MISR versus using only MODIS were found to be negligible (not shown).

\subsubsection{MERRA-2 AOD reanalysis}

As part of the upgrade from the original MERRA reanalysis (Rienecker et al., 2011) based on the Goddard Earth Observing System (GEOS) Earth system model, MERRA2 now incorporates assimilation of AOD from a variety of remote sensing sources, including AERONET, MODIS, and MISR after 2000, as well as the Advanced Very High Resolution Radiometer (AVHRR) before 2002. The aerosol module used for MERRA-2 is the Goddard Chemistry, Aerosol, Radiation, and Transport model (GOCART; Chin et al., 2000; Colarco et al., 2010), which provides simulations of dust, sea salt, black and organic carbon, and sulfate aerosols, and is run radiatively coupled to the GEOS Atmospheric Global Climate Model (AGCM). A detailed description and validation of the AOD reanalysis product can be found in Randles et al. (2017) and Buchard et al. (2017). For the purpose of this study, monthly mean DAOD at $550 \mathrm{~nm}$ with $0.5^{\circ}$ latitude and $0.625^{\circ}$ longitude spatial resolution is used. MERRA-2's longer data record (1981-present) would have made it an ideal candidate for a longer-period analysis of the relationship between DAOD and TCs. However, the volcanic eruptions of El Chichón (1982) and Pinatubo (1991) result in high AOD for several years following each event, and the particle property assumptions in MERRA-2 do not properly apportion the assimilated AOD increments among the simulated aerosol species. For the 2003-2018 time period, MERRA- 
2 AOD data have similar validation statistics compared to NAAPS-RA and CAMSRA at the sites located off of the coast of West Africa and the Caribbean, as shown in Table 1.

\subsubsection{CAMSRA AOD reanalysis}

Under the banner of the Copernicus Atmosphere Monitoring Service (CAMS), operated by ECMWF on behalf of the European Commission, a new global reanalysis of atmospheric composition has been produced: CAMSRA (Inness et al., 2019). This is the successor to the MACC reanalysis (Inness et al., 2013) and CAMS interim reanalysis (Flemming et al., 2017) produced previously at ECMWF. The dataset spans the period 2003-2018 and is being continued for subsequent years. The model component is based on the same Integrated Forecasting System (IFS) used at ECMWF for weather forecasting and meteorological reanalysis but at a coarser resolution and with additional modules activated for prognostic aerosol species (dust, sea salt, organic matter, black carbon, and sulfate) and trace gases. The impact of the aerosols (and ozone) on radiation and thereby on meteorology is included in the model. For aerosols, observations of total AOD at $550 \mathrm{~nm}$ are assimilated from MODIS (Terra and Aqua) for the whole period and from the Advanced Along-Track Scanning Radiometer for 2003-2012, using a 4D variational data assimilation system with a $12 \mathrm{~h}$ data assimilation window along with meteorological and trace gas observations. The speciated AOD products used in this study are available at a 3-hourly temporal resolution and a $\sim 0.7^{\circ}$ spatial resolution. Model development has generally improved the speciation of aerosols compared with earlier reanalyses, and evaluation against AERONET is largely consistent over the period of the reanalysis. There is a known issue regarding a significant overestimation of sulfate near outgassing volcanoes; however this is unlikely to have much relevance to the regions considered in this study.

\subsubsection{AOD multi-reanalysis consensus (MRC)}

Based on the three aerosol reanalysis products described above, we made a MRC product following the multimodel-ensemble method of the International Cooperative for Aerosol Prediction (ICAP, Sessions et al., 2015; Xian et al., 2019). The MRC is a consensus mean of the three individual reanalyses, with a $1^{\circ} \times 1^{\circ}$ degree spatial and monthly temporal resolution. Speciated AODs and total AOD at $550 \mathrm{~nm}$ for 2003-2018 are available. This new product is validated with ground-based AERONET observations for Africandust-influenced regions, including the western coast of North Africa and the Caribbean Sea. Validation results in terms of root mean square error (RMSE) for total and coarse-mode AODs are presented in Table 1. Similar to the ICAP multimodel-ensemble evaluation result, the MRC is found to generally be the top performer among all of the reanalyses for the study region.

\subsubsection{AErosol RObotic NETwork (AERONET) fine- and coarse-mode AOD}

AERONET is a ground-based global-scale sun photometer network that includes instruments to measure sun and sky radiance at wavelengths ranging from the near ultraviolet to the near infrared during daytime hours. This network has been providing high-accuracy and high-quality measurements of aerosol properties since the 1990s (Holben et al., 1998; Holben et al., 2001) and is often used as the primary dataset for validating aerosol optical properties in satellite retrievals and model simulations (e.g., Levy et al., 2010; Colarco et al., 2010; Kahn and Gaitley, 2015). Only cloudscreened, quality-assured version 3 Level 2 AERONET data are utilized in this study (Giles et al., 2019). AERONET multiple wavelength measurements were used to derive both fine- and coarse-mode AODs at $550 \mathrm{~nm}$ based on the spectral deconvolution method (SDA) of O'Neill et al. (2003). The SDA product was verified with in situ measurements (Kaku et al., 2014) and was shown to be able to capture the full modal properties of fine and coarse particles. Temporally, AERONET data are averaged into $6 \mathrm{~h}$ bins centered at the regular model output times of 00:00, 06:00, 12:00, and 18:00 UTC. Monthly mean AERONET AOD is derived only when the total number of $6 \mathrm{~h}$ AERONET data is greater than 18 to ensure temporal representativeness.

\subsection{Tropical cyclone data - HURDAT2}

Atlantic basin TC data were taken from the Atlantic hurricane database version 2 (HURDAT2; Landsea and Franklin, 2013). This dataset contains 6-hourly information (including position, maximum sustained winds, and central pressure where available) for every TC observed in the Atlantic basin dating back to 1851 .

\subsection{Atmospheric data - ERA-Interim reanalysis}

The ERA-Interim reanalysis (Dee et al., 2011) is a global atmospheric reanalysis produced by the ECMWF that uses a four-dimensional variational analysis with a $12 \mathrm{~h}$ analysis window. The spectral resolution of these data is approximately $80 \mathrm{~km}$ (T255), is available on 60 vertical levels from the surface to $0.1 \mathrm{hPa}$, and is available from January 1979 to August 2019. We use monthly mean large-scale fields, including vector wind, atmospheric temperature, and relative humidity data on several pressure levels.

\subsection{Oceanic data - NOAA OI SST}

The National Oceanic and Atmospheric Administration (NOAA) Optimum Interpolation (OI) SST product (Reynolds et al., 2002) is utilized for SST calculations. NOAA OI SST v2 uses a combination of in situ data, satellite data, SSTs simulated by sea-ice cover, and bias adjustments to arrive at its final estimate of SSTs. NOAA OI SST v2 
Table 1. Root mean square error of total AOD (left number in each cell) and coarse-mode AOD (right number in each cell) at $550 \mathrm{~nm}$ from individual aerosol reanalyses, including CAMSRA, MERRA-2, NAAPS-RA, and the multi-reanalysis consensus (MRC) verified with AERONET V3L2 monthly data for the 2003-2018 time period. The rank of MRC among all reanalyses in terms of root mean square error (RMSE) is also shown. " " means there are ties in the ranking. The first five sites are located in North Africa or off of the northwestern coast of Africa. The last four sites are located in or near the Caribbean Sea. AOD time series of MRC and AERONET at Dakar, Cabo Verde, Ragged Point, and La Parguera sites are presented in Fig. 3.

\begin{tabular}{lrrrrr}
\hline Site & CAMSRA & MERRA-2 & NAAPS-RA & MRC & Rank of MRC \\
\hline Banizoumbou & $0.13 \mid 0.17$ & $0.10 \mid 0.10$ & $0.11 \mid 0.13$ & $0.10 \mid 0.11$ & $\sim 1 \mid 2$ \\
Cabo Verde & $0.07 \mid 0.07$ & $0.06 \mid 0.05$ & $0.06 \mid 0.07$ & $0.06 \mid 0.06$ & $\sim 1 \mid 2$ \\
Dakar & $0.07 \mid 0.11$ & $0.07 \mid 0.07$ & $0.08 \mid 0.10$ & $0.06 \mid 0.08$ & $1 \mid 2$ \\
La Laguna & $0.06 \mid 0.05$ & $0.06 \mid 0.05$ & $0.06 \mid 0.05$ & $0.05 \mid 0.04$ & $1 \mid 1$ \\
Santa Cruz Tenerife & $0.04 \mid 0.04$ & $0.04 \mid 0.04$ & $0.04 \mid 0.04$ & $0.03 \mid 0.03$ & $1 \mid 1$ \\
Ragged Point & $0.05 \mid 0.03$ & $0.03 \mid 0.03$ & $0.03 \mid 0.03$ & $0.04 \mid 0.03$ & $3 \mid \sim 1$ \\
La Parguera & $0.05 \mid 0.02$ & $0.03 \mid 0.02$ & $0.03 \mid 0.02$ & $0.03 \mid 0.02$ & $\sim 1 \mid \sim 1$ \\
Guadeloupe & $0.05 \mid 0.05$ & $0.05 \mid 0.04$ & $0.04 \mid 0.05$ & $0.04 \mid 0.04$ & $\sim 1 \mid \sim 1$ \\
Key Biscayne & $0.05 \mid 0.03$ & $0.03 \mid 0.02$ & $0.02 \mid 0.02$ & $0.03 \mid 0.02$ & $2 \mid \sim 1$ \\
\hline
\end{tabular}

data are available on a $1^{\circ} \times 1^{\circ}$ grid from November 1981 to present.

\subsection{Climate indices}

The Oceanic Niño Index (ONI), defined to be a 3-month average of the Niño $3.4\left(5^{\circ} \mathrm{S}-5^{\circ} \mathrm{N}, 170-120^{\circ} \mathrm{W}\right)$ index (Barnston et al., 1997) based on centered 30-year periods which are updated every 5 years, is utilized to represent the state of the El Niño-Southern Oscillation (ENSO). This index is also used by NOAA to identify ENSO events.

The SST component of the AMM (Kossin and Vimont, 2007) is investigated to assess the relationship between DAOD and tropical Atlantic oceanic conditions. While the index is not standardized, we have standardized it by its 1981-2010 average and standard deviation.

\subsection{Derived tropical cyclone indices}

The genesis potential index (GPI) was calculated using monthly-averaged ERA-Interim data following Emanuel and Nolan (2004). The maximum potential intensity (MPI) was calculated using monthly-averaged ERA-Interim temperature and moisture and NOAA OI SST following Bister and Emanuel (2002).

\section{Results}

\subsection{Dust aerosol optical depth over the MDR (2003-2018)}

Figure 2 shows the MRC monthly DAOD climatology based on the 2003-2018 average as well as the ratio of DAOD to total AOD for June-October over the tropical Atlantic. Climatologically from June to October, the majority of airborne dust originates from the Sahara Desert, in contrast to the winter season when a significant amount of dust is emitted over the Sahel and southern Sahara (Engelstaedter and Washington, 2007). This dust is then transported westward over the Atlantic and eventually to the Caribbean, largely within the $10-25^{\circ} \mathrm{N}$ latitude belt. The transported African dust covers most of the Atlantic hurricane MDR, which spans the tropical North Atlantic and Caribbean. The DAOD over the Atlantic is, on average, much higher in June, July, and August (JJA) than in September and October because of higher emissions over the African continent in the former months (Carlson and Prospero, 1972; Engelstaedter and Washington, 2007; Dunion and Marron, 2008; Dunion, 2011). DAOD is also much higher over the tropical Atlantic than over the Caribbean, as dust aerosols are removed by wet and dry processes during the long-range transport. The MRC shows that dust aerosols are the dominant contributor to the total AOD in the MDR during most of the hurricane season (JuneOctober). The DAOD accounts for about $50 \%-60 \%$ of the total AOD over the tropical North Atlantic and around $30 \%-$ $50 \%$ over the Caribbean for JJA. This suggests that the total AOD can be a relatively good indicator of DAOD in the tropical North Atlantic but is not as good of an indicator in the Caribbean for JJA. The DAOD contribution to total AOD is about $10 \%-20 \%$ less for September and October. Considering the potential larger forcing by airborne dust in JJA than in September and October, the focus season in this study is JJA.

As transport of Saharan dust across the Atlantic during summer is often associated with SAL outbreaks, which are approximately centered around $700 \mathrm{hPa}$ (Dunion and Velden, 2004; Dunion, 2011), monthly climatological $700 \mathrm{hPa}$ relative humidity $(\mathrm{RH})$ and horizontal wind are also shown in Fig. 2. Climatologically, the MDR is dominated by the mid-level easterly jet $\left(7-8 \mathrm{~m} \mathrm{~s}^{-1}\right)$ during JJA and weaker easterlies $\left(5-6 \mathrm{~m} \mathrm{~s}^{-1}\right)$ during September and October. Over the Caribbean, the wind direction veers slightly towards the north for all of the studied months and relates to this re- 

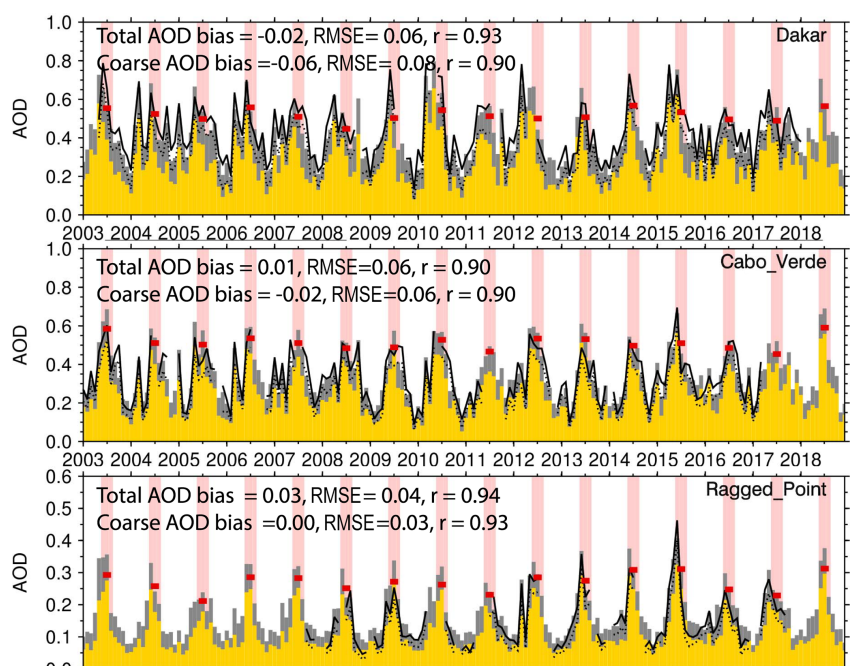

2003200420052006200720082009201020112012201320142015201620172018

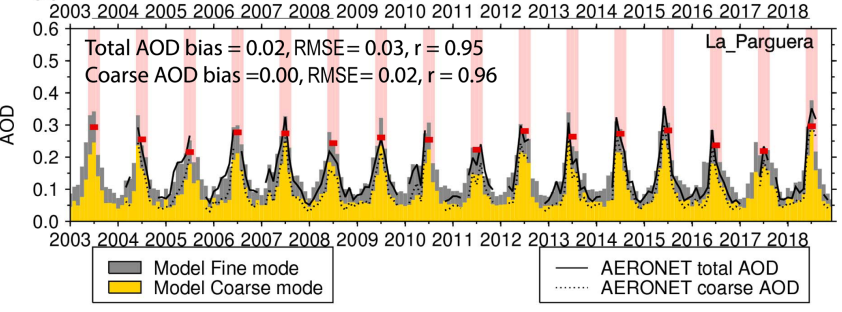

Figure 3. Monthly mean version 3 L2 AERONET and MRC $550 \mathrm{~nm}$ modal AODs at four African dust-impacted sites: Dakar, Cabo Verde, Ragged Point, and La Parguera from east to west. JJA are highlighted with pink shading, and JJA seasonal average total AODs from MRC are shown with red bars. Annotations for each time series show bias, RMSE, and correlation ( $r$ ) of monthly averages calculated from the MRC.

gion being typically positioned on the west side of the climatological Atlantic subtropical ridge. The $700 \mathrm{hPa} \mathrm{RH}$ is on the order of $40 \%$ and $50 \%$ for the tropical Atlantic and the Caribbean respectively for JJA and is about $10 \%$ higher in September and October. RH is higher in the Caribbean than in the tropical North Atlantic as the impact of dry air from the SAL and from upper-level subsidence becomes weaker from east to west. For context, the Atlantic moist tropical sounding, defined in Dunion (2011), has average $700 \mathrm{hPa}$ winds of $3.6 \mathrm{~m} \mathrm{~s}^{-1}$ at $112^{\circ}$ (wind direction) and $66 \% \mathrm{RH}$, while the mean SAL sounding has corresponding values of $7.8 \mathrm{~m} \mathrm{~s}^{-1}$ at $91^{\circ}$ and $34 \% \mathrm{RH}$.

Figure 3 shows the monthly mean AERONET version $3 \mathrm{~L} 2$ and MRC $550 \mathrm{~nm}$ modal AOD time series at four AERONET sites that are primarily influenced by African dust. From east to west, these sites include Dakar, Senegal $\left(14.4^{\circ} \mathrm{N}, 17.0^{\circ} \mathrm{W}\right)$; Cabo Verde $\left(16.7^{\circ} \mathrm{N}, 22.9^{\circ} \mathrm{W}\right)$; Ragged Point, Barbados $\left(13.2^{\circ} \mathrm{N}, 59.4^{\circ} \mathrm{W}\right)$; and La Parguera, Puerto Rico $\left(18.0^{\circ} \mathrm{N}, 67.0^{\circ} \mathrm{W}\right)$, which are also marked in Fig. 1. The boreal summer peak dust activity (i.e., JJA) is highlighted. Dust aerosols are typically considered coarse mode, although there may be a very small amount of mass in fine mode. The fine-mode AOD observed in AERONET measurements for these sites are normally dominated by pollution and biomass-burning smoke. Dakar and Cabo Verde experience dust aerosols throughout the year, with a peak in JJA and a weaker secondary peak during the boreal winter, which is associated with dust emissions from the Sahel. The Ragged Point and La Parguera sites, which are remote receptor sites in the Caribbean, are influenced by African dust predominantly during boreal summer, thus displaying a pronounced peak of total and coarse-mode AODs in JJA. The secondary AOD peak during winter at Dakar and Cabo Verde is generally not observed at Ragged Point or La Parguera, as African dust is transported to the south following the low-to-midlevel trade wind flow, occasionally reaching South America (Prospero, 2014).

Figure 3 also shows the bias, the root mean square error (RMSE) of MRC, and the correlation $(r)$ between MRC and AERONET for monthly AODs at each of the four AERONET sites. Overall, MRC follows the seasonal and interannual variability in AERONET data for the total AOD quite well and to a slightly lesser extent for the coarse-mode AOD. Coarse-mode aerosols include dust and sea salt but are dominated by dust aerosols over the tropical North Atlantic for JJA (Fig. 2c, speciated AOD cannot be obtained from AERONET measurements). The correlation is $>\sim 0.9$ for the coarse-mode AOD and tends to be better at the long-range transport sites (i.e., Ragged Point and La Parguera) than the sites close to the dust source (i.e., Dakar and Cabo Verde). The correlation is slightly lower in the source area than in the long-range transport region because there are large uncertainties in emissions and strong gradients due to local aerosol sources in the source area. Also, the source area allows less time for AOD data assimilation to correct aerosol mass loads, in addition to a lower signal-to-noise ratio of AOD retrievals over land than over water (e.g., Levy et al., 2005). The small bias, low RMSE and the high correlation with AERONET data illustrate the ability of MRC to capture the aerosol environment in the MDR. In addition, all of the three individual aerosol reanalyses that form the foundation of MRC have similar verification scores against AERONET, though the MRC typically has a better verification score than the individual reanalyses (Table 1). If we were to give different qualitative ratings for the three individual reanalyses for the study area, MERRA-2 would be slightly better over North Africa and NAAPS-RA would be slightly better over the Caribbean in terms of coarse-mode and total AOD RMSEs.

Figure 4 shows the time series of monthly mean and regionally averaged DAOD from MRC and the three contributing reanalyses from 2003 to 2018 for the tropical North Atlantic and Caribbean as defined in Fig. 2. The DAODs from the three reanalyses have similar seasonal and interannual variability and are highly correlated, with $r \geq 0.95$ for the entire 16-year period and $r \geq 0.85$ for JJA for both regions based on monthly means. The magnitudes of JJA 


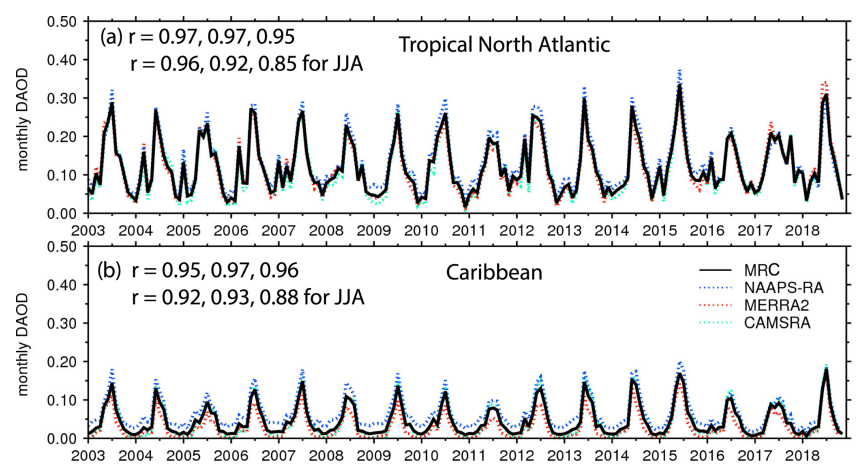

Figure 4. Monthly DAOD at $550 \mathrm{~nm}$ from CAMSRA, MERRA2, NAAPS-RA, and MRC from 2003 to 2018 for the (a) tropical North Atlantic and the (b) Caribbean. Correlations between CAMSRA and MERRA-2, CAMSRA and NAAPS-RA, and MERRA-2 and NAAPS-RA are displayed in sequence for all months and for JJA-only respectively.

DAOD from the three individual reanalyses are comparable over the tropical North Atlantic, with a $20 \%$ maximum difference among the three products based on JJA DAOD. The climatological average of JJA DAOD over the tropical North Atlantic is 0.21 . The difference can be as much as $\sim 0.06$ ( $\sim 60 \%$ difference between member products) for the Caribbean. The climatological average of JJA DAOD in the Caribbean is 0.10. Since the total and coarse-mode AOD verification statistics for the three products at the Caribbean AERONET sites are similar (Table 1), the DAOD difference is most likely due to the different partitioning of aerosol species (e.g., dust versus sea salt aerosols) during the total AOD data assimilation process. This is related to the fact that total AOD is the only aerosol property constrained by satellite observations through AOD data assimilation in all three aerosol reanalysis products, while speciated AOD is not constrained (Lynch et al., 2016; Randles et al., 2017; Inness et al., 2019). Nevertheless, the DAOD from the MRC is likely the most reliable given the generally better performance of a multi-aerosol model consensus compared to individual aerosol models (Sessions et al., 2015; Xian et al., 2019).

\subsection{Relationship between North Atlantic TC activity and JJA DAOD}

Accumulated cyclone energy (ACE) is often utilized to represent TC activity and is defined to be the square of the 1 min maximum sustained wind speed at each 6-hourly interval when a tropical or subtropical cyclone (with maximum sustained winds $\geq 34 \mathrm{kt}$ ) is present (Bell et al., 2000). Basinwide ACE is used here, as it is assumed that MDR conditions affect to some extent the ACE of all storms that pass through the MDR, including those that later moved out of the MDR. For example, we hypothesize that in an active dust year the suppressed conditions in the MDR would make for weaker,
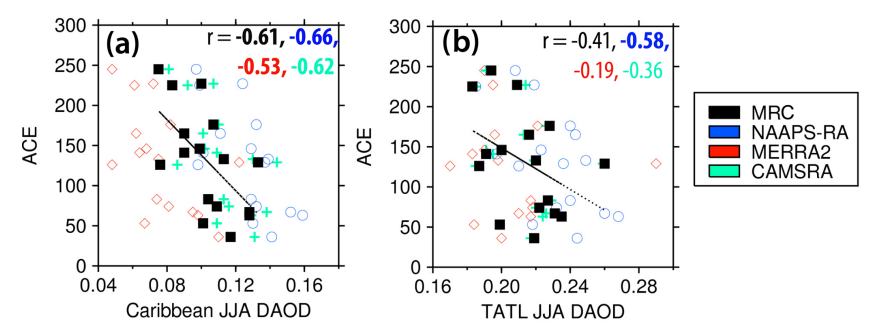

Figure 5. Scatterplot showing the relationship between annual Atlantic accumulated cyclone energy (ACE) and JJA region-averaged DAOD from MRC, NAAPS-RA, MERRA-2, and CAMSRA over the (a) Caribbean and (b) the tropical North Atlantic. One unit of ACE equals $10^{4} \mathrm{kt}^{2}$. Correlations $(r)$ between ACE and DAOD are color-coded for different DAOD products and overlaid on each plot, and statistically significant correlations are in bold. The possible causes of the DAOD difference between the reanalysis products are discussed in Sect. 3.1.

less organized AEWs that have less of a chance for formation even if they do eventually move out of the MDR. Later we show in Table 2 that using ACE generated in the Caribbean domain yields a consistent (same sign) yet stronger correlation relationship between DAOD and ACE.

Atlantic TC activity shows a statistically significant relationship with regionally averaged Caribbean JJA DAOD. Figure 5a displays this relationship, with higher Caribbean DAOD correlating $(r=-0.61$ with MRC DAOD and $r$ of similar magnitudes from all three individual reanalyses and exceeding the two-tailed $95 \%$ statistical significance level) with quieter Atlantic hurricane seasons as quantified by ACE. While tropical North Atlantic DAOD and Caribbean DAOD in JJA correlate strongly $(r=0.88)$, Fig. $5 \mathrm{~b}$ shows that the relationship between DAOD and ACE is weaker in the tropical North Atlantic than in the Caribbean. The correlation between tropical North Atlantic DAOD and ACE is -0.41, which falls below the statistical significance threshold (correlations with MERRA-2 and CAMSRA DAODs are also insignificant). We will show in the next section that the relationship between large-scale fields known to impact Atlantic TC activity also tends to have higher correlations with JJA Caribbean DAOD than with JJA tropical North Atlantic DAOD.

Given the strength of the relationship between Caribbean DAOD and seasonal Atlantic ACE, we next investigate the relationship in extreme JJA DAOD seasons. We take the three seasons from 2003 to 2018 when JJA Caribbean DAOD was at its highest levels and when it was at its lowest levels.

The three seasons with the highest JJA Caribbean DAOD were 2018, 2015, and 2014 in descending order, and the three seasons with the lowest JJA Caribbean DAOD were 2005, 2011, and 2017 in ascending order based on MRC. The left column of Fig. 6 shows DAOD composites for the three high-JJA-Caribbean-DAOD seasons and the three lowJJA-Caribbean-DAOD seasons and their differences. DAOD 
Table 2. Annual average Atlantic TC activity in the three seasons with the highest JJA Caribbean DAOD (2014, 2015, and 2018) and the three seasons with the lowest JJA Caribbean DAOD (2005, 2011 and 2017). Ratios between the three low-DAOD seasons and the three high-DAOD seasons are also provided. Corresponding numbers for the Caribbean are provided in parentheses next to the total basin-wide numbers.

\begin{tabular}{lrrrrr}
\hline & $\begin{array}{r}\text { Tropical } \\
\text { depressions } \\
\text { and named } \\
\text { storms }\end{array}$ & $\begin{array}{r}\text { Named } \\
\text { storms }\end{array}$ & Hurricanes & $\begin{array}{r}\text { Major } \\
\text { hurricanes }\end{array}$ & $\begin{array}{r}\text { Accumulated } \\
\text { cyclone } \\
\text { energy }\end{array}$ \\
\hline $\begin{array}{l}\text { Three } \\
\text { highest JJA } \\
\text { Caribbean }\end{array}$ & $12.3(2.3)$ & $11.3(2.3)$ & $6.0(0.3)$ & $2.0(0.0)$ & $86(3)$ \\
DAOD & & & & & \\
\hline $\begin{array}{l}\text { Three } \\
\text { lowest JJA } \\
\text { Caribbean }\end{array}$ & $23.0(6.7)$ & $21.3(6.7)$ & $10.7(3.0)$ & $5.7(2.7)$ & $199(39)$ \\
DAOD & & & & & \\
\hline Ratio & $1.9(2.9)$ & $1.9(3.0)$ & $1.8(9.0)$ & $2.8($ N/A) & $2.3(13.0)$ \\
\hline
\end{tabular}

is not only higher over the MDR in the high-CaribbeanDAOD seasons, but dust aerosols are also transported farther to the west. DAOD differences between the extreme highand low-DAOD seasons over the tropical North Atlantic and Caribbean are $\sim 0.05-0.08$. In fact, the 3 high-dust years have roughly $60 \%$ more DAOD in the Caribbean than the 3 low-dust years (regional average of 0.13 vs. 0.08 ), while these differences are not as large in the tropical North Atlantic. The transport pathway of dust is also shifted slightly to the south in the tropical North Atlantic in the three highDAOD seasons.

The right column of Fig. 6 displays the JJA-averaged $850 \mathrm{hPa}$ winds and $700 \mathrm{hPa} \mathrm{RH}$ for the three high-JJACaribbean-DAOD seasons and three low-JJA-CaribbeanDAOD seasons, as well as the difference between these high- and low-DAOD seasons. Large-scale conditions over the Caribbean during JJA were much less conducive for TCs in the high-DAOD seasons, with drier middle levels ( $>10 \%$ relative humidity difference) and stronger easterly trade winds (2-4 $\mathrm{m} \mathrm{s}^{-1}$ stronger), implying an overall lesshurricane-favorable dynamic and thermodynamic environment. This is consistent with the depiction of the thermodynamic structure of the SAL by Dunion and Velden (2004). The stronger AEJ associated with higher DAOD is also consistent with modeling studies when aerosol radiative effects are taken into account (Tompkins et al., 2005). Associated with high Caribbean DAOD, the position of the center of the Azores High was slightly shifted to the southwest, which facilitates stronger dust transport into the Caribbean. This is in agreement with the findings of Riemer et al. (2006), who suggested the importance of the position of the Azores High in African dust transport across the Atlantic, although their study was only during the boreal winter. As would be ex- pected from these large-scale conditions, Atlantic TC activity was much higher in low-JJA-Caribbean-DAOD seasons.

Table 2 displays observed Atlantic TC activity as well as the ratios of observed average seasonal Atlantic TC activity in the three low-JJA-Caribbean-DAOD seasons versus the three high-Caribbean-DAOD seasons. Atlantic basinwide numbers of tropical depressions, named storms, hurricanes, major (Category 3+ on the Saffir-Simpson Hurricane Wind Scale) hurricanes, and ACE, are higher by a factor of $\sim 1.9-2.8$ in the three low-Caribbean-DAOD seasons relative to the three high-Caribbean-DAOD seasons. The ratios are even higher (e.g., 12 times higher for ACE) for TC activity in the Caribbean. The 2018 Atlantic hurricane season was an interesting case, as it was an above-average overall hurricane season (as measured by ACE), but much of the ACE that was generated that year occurred outside of the tropics $\left(>23.5^{\circ} \mathrm{N}\right)$ (Saunders et al., 2020). Very little TC activity occurred in the Caribbean in 2018.

In addition, the ratio for major hurricanes is higher than the ratios for tropical depressions, named storms and hurricanes, indicating a stronger relationship between dust aerosols and intense storms than between dust aerosols and weak storms. A total of 17 major hurricanes were observed in the Atlantic in the three low-Caribbean-DAOD seasons, compared with only 6 major hurricanes in the three high-Caribbean-DAOD seasons. The three low-Caribbean-DAOD seasons had six continental United States major hurricane landfalls (2005 hurricanes Dennis, Katrina, Rita, and Wilma and 2017 hurricanes Harvey and Irma), while the three high-CaribbeanDAOD seasons had one continental United States major hurricane landfall (2018 Hurricane Michael).

Figure 7 displays the named storm formation location of all Atlantic TCs in the three seasons with the highest JJA Caribbean DAOD and the three seasons with the 

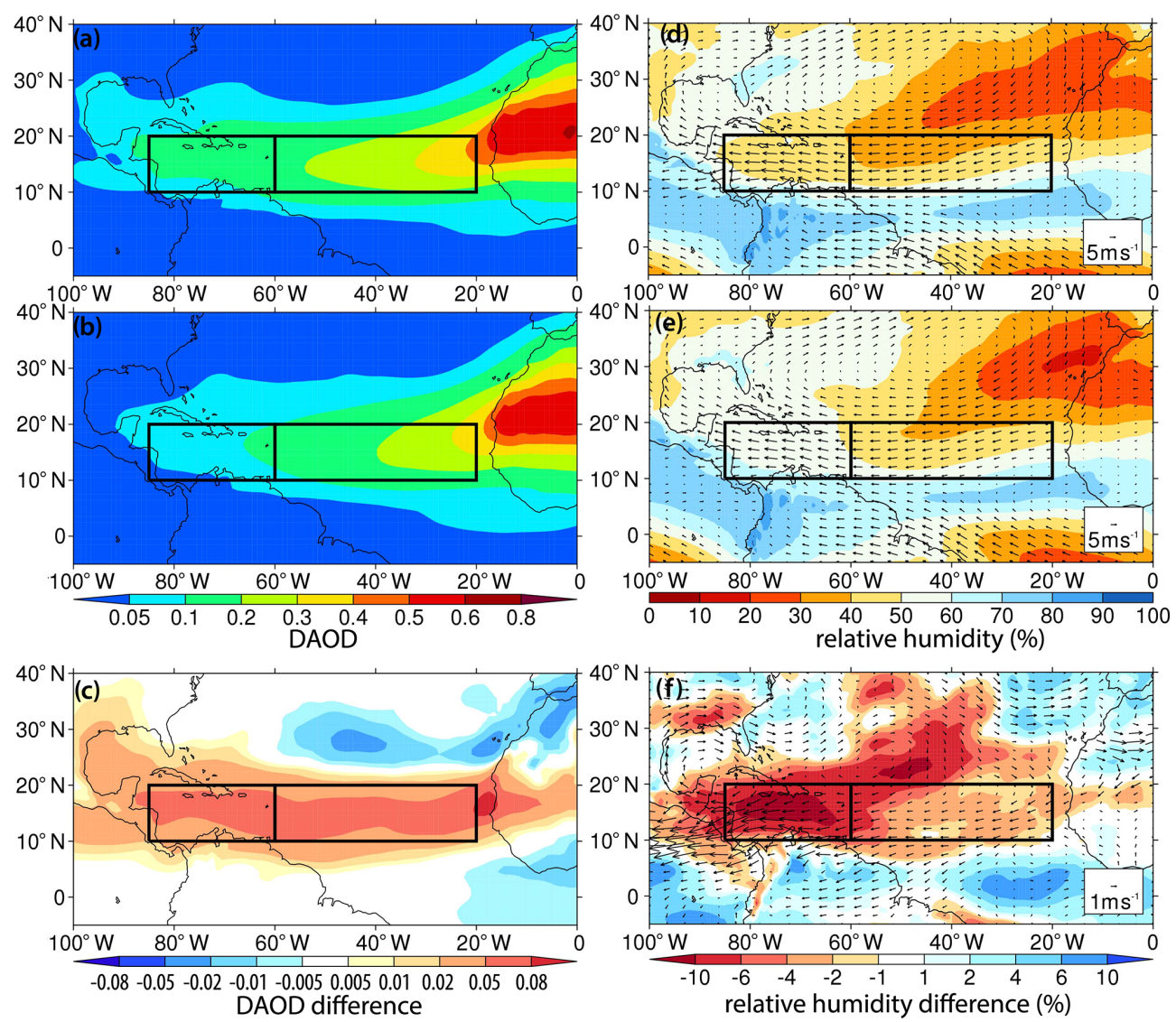

Figure 6. (a, b, c) MRC JJA composite of DAOD for the three Atlantic hurricane seasons from 2003 to 2018 with (a) the highest JJA Caribbean DAOD (2014, 2015, and 2018), (b) the lowest JJA Caribbean DAOD (2005, 2011, and 2017), and (c) the difference between the two (highest minus lowest). (d, e, f) the corresponding JJA composite of $850 \mathrm{hPa}$ wind (vectors) and $700 \mathrm{hPa} \mathrm{RH}$ (color shading).

lowest Caribbean DAOD along with the maximum intensity that these TCs reached. As would be expected from the differences in large-scale conditions noted earlier, TCs that became major hurricanes formed much more frequently south of $20^{\circ} \mathrm{N}$ in the three lowest-Caribbean-DAOD seasons than in the three highest-Caribbean-DAOD seasons. These differences were most pronounced in the Caribbean, with only one named storm (Hanna in 2014) forming in the Caribbean in the three highest-JJA-Caribbean-DAOD seasons. In the three lowest-Caribbean-JJA-DAOD seasons, 11 named storms formed in the Caribbean.

\subsection{Relationship between JJA DAOD and large-scale atmosphere/ocean fields}

We next examine the relationship between JJA DAOD and large-scale atmosphere/ocean fields. In this analysis, we begin by focusing on several fields that have been documented in prior research to significantly impact Atlantic TC activity: $850 \mathrm{hPa}$ zonal wind $(850 \mathrm{hPa} U), 200 \mathrm{hPa}$ zonal wind $(200 \mathrm{hPa} U)$, zonal wind shear between 200 and $850 \mathrm{hPa}$, $700 \mathrm{hPa} \mathrm{RH}, 850 \mathrm{hPa}$ relative vorticity, and SST (Gray,
1968; Saunders et al., 2017). More active Atlantic hurricane seasons are typically associated with anomalous westerly $850 \mathrm{hPa} U$ (e.g., weaker trade winds); anomalous easterly $200 \mathrm{hPa} U$ (counteracting prevailing upper-level westerlies); and thus weaker wind shear, higher $850 \mathrm{hPa}$ relative vorticity, higher mid-level relative humidity and anomalously warm SSTs. We investigate the relationships with DAOD in the tropical North Atlantic and the Caribbean as defined in Fig. 2.

Figure 8 displays the correlation between regionally averaged MRC JJA DAOD in the Caribbean and the six largescale fields just discussed. Higher JJA Caribbean DAOD is associated with stronger $850 \mathrm{hPa}$ easterly trades and increased $200 \mathrm{hPa}$ upper-level westerlies (and hence stronger vertical wind shear), drier air at $700 \mathrm{hPa}$, and anomalously cool SST across the MDR. Weaker $850 \mathrm{hPa}$ relative vorticity also predominates over most of the Caribbean. However, almost no correlation is found between Caribbean JJA DAOD and $850 \mathrm{hPa}$ relative vorticity in the tropical North Atlantic, possibly due to the counteracting role of covariability of African dust emissions and AEWs - as was inferred from a positive correlation between the two by Karyam- 
(a)

(b)
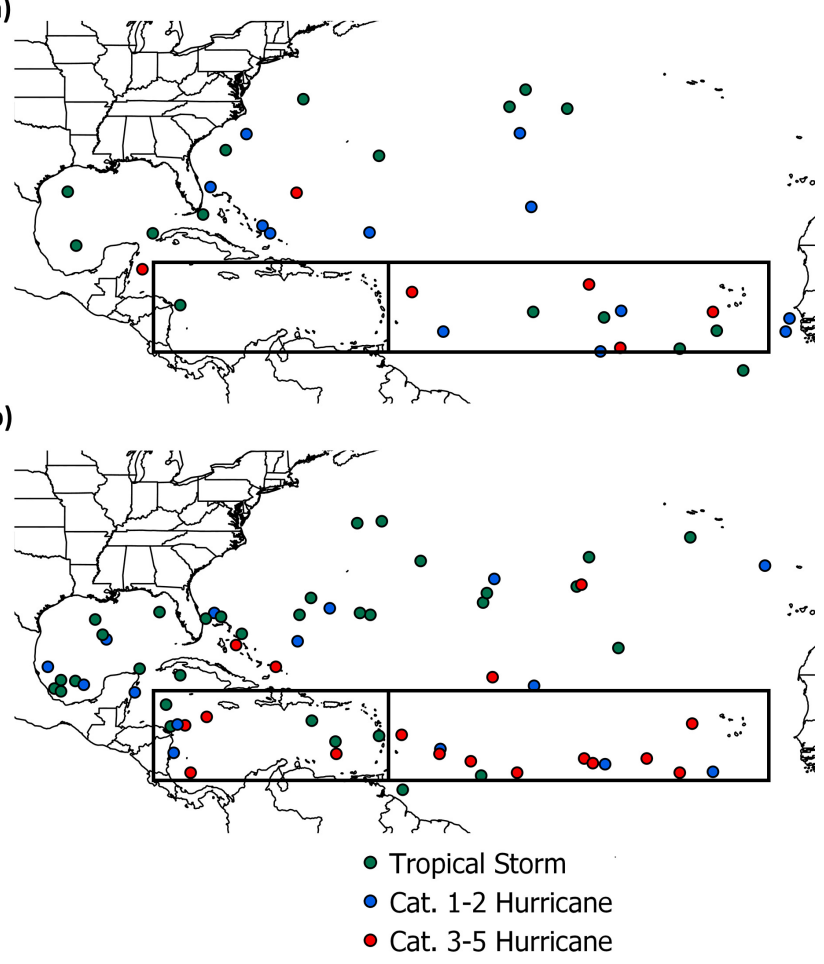

Figure 7. Formation locations of Atlantic named storms during the three seasons with (a) the highest Caribbean JJA DAOD (2014, 2015, and 2018) and (b) the lowest Caribbean JJA DAOD (2005, 2011, and 2017). Also displayed is the maximum intensity that each TC reached.

pudi and Carlson (1988). This result is also consistent with Fig. 7, which shows more named storms and therefore likely stronger AEW activity right off of the coast of west Africa between 10 and $20^{\circ} \mathrm{N}$ in high-DAOD years. This result reflects the complexity of the TC-dust interaction relationship. In addition, the vorticity field is extremely noisy. Figure $8 \mathrm{f}$ is extended to include the eastern and central tropical Pacific in order to investigate the potential relationship between ENSO and DAOD, with Caribbean DAOD showing a significant positive relationship with ENSO.

The relationship between the same six large-scale fields and JJA tropical North Atlantic DAOD is considerably weaker, with lower correlations observed for all six fields (Fig. S2). In addition, the regions with significant correlations decrease in spatial extent relative to the Caribbean DAOD correlations shown in Fig. 8.

We next investigate maximum potential intensity (MPI), an integrated TC index, which combines a list of key factors (similar to those explored above). MPI assesses how conducive atmospheric thermodynamic conditions are for TC intensification, providing a theoretical limit of the strength of a TC (Holland, 1997; Bister and Emanuel, 1998). Figure $9 \mathrm{a}$ and $\mathrm{c}$ show the correlations between the Caribbean region-averaged JJA DAOD and JJA and ASO (August,
Table 3. Correlation matrix between regionally averaged multireanalysis consensus (MRC) JJA tropical North Atlantic/Caribbean DAOD and $850 \mathrm{hPa} U, 200 \mathrm{hPa} U, 200 \mathrm{hPa}$ minus $850 \mathrm{hPa} U$ (zonal wind shear), $700 \mathrm{hPa} \mathrm{RH}, \mathrm{SST}$, maximum potential intensity (MPI), and genesis potential index (GPI) during JJA and ASO, respectively. Correlations that are statistically significant at the $90 \%$ level are highlighted in bold, and those with asterisks are statistically significant at the $95 \%$ level. $850 \mathrm{hPa}$ relative vorticity is not shown as none of these correlations were statistically significant.

\begin{tabular}{|c|c|c|}
\hline Environmental field & $\begin{array}{r}\text { JJA tropical } \\
\text { North } \\
\text { Atlantic/JJA } \\
\text { Caribbean }\end{array}$ & $\begin{array}{r}\text { ASO tropical } \\
\text { North } \\
\text { Atlantic/ASO } \\
\text { Caribbean }\end{array}$ \\
\hline $850 \mathrm{hPa} U$ & $-0.63^{*} /-0.79^{*}$ & $0.03 /-\mathbf{0 . 6 6}{ }^{*}$ \\
\hline $200 \mathrm{hPa} U$ & $0.34 / \mathbf{0 . 8 1}{ }^{*}$ & $0.30 / \mathbf{0 . 8 5} *$ \\
\hline 200 minus $850 \mathrm{hPa} U$ & $0.43 / \mathbf{0 . 8 3}^{*}$ & $0.22 / \mathbf{0 . 8 2} *$ \\
\hline $700 \mathrm{hPa} \mathrm{RH}$ & $-0.43 /-\mathbf{0 . 8 0} *$ & $-0.34 /-\mathbf{0 . 5 5}{ }^{*}$ \\
\hline SST & $-0.71^{*} /-0.75^{*}$ & $-0.44 /-0.79 *$ \\
\hline MPI & $-0.74^{*} /-0.68^{*}$ & $-0.47 /-0.67^{*}$ \\
\hline GPI & $-0.75^{*} /-0.76^{*}$ & $-0.62^{*} /-0.69^{*}$ \\
\hline
\end{tabular}

September, and October) MPI calculated based on Bister and Emanuel (1998). Consistent with the results for the individual large-scale fields, JJA MPI over the MDR exhibits strong negative correlations with JJA Caribbean DAOD $(\sim-0.7$, also Table 3). One of the primary inputs to the MPI calculation is SST, so the strong inverse relationship between MPI and DAOD is expected given the strong inverse relationship between SST and DAOD. The correlation is significant but weaker for ASO MPI for most of the MDR, except for the eastern tropical North Atlantic, where the negative correlation drops below statistical significance. The negative correlation of JJA and ASO MPI with JJA tropical North Atlantic region-averaged DAOD is much weaker than that with JJA Caribbean DAOD in the MDR (Fig. 9b and d) and drops below statistical significance in the Caribbean.

The genesis potential index (GPI) is another integrated TC index that is often used to provide an estimate of the potential for tropical cyclogenesis (e.g., Emanuel and Nolan, 2004; Camargo et al., 2007). Monthly GPI is calculated following Emanuel and Nolan (2004). Figure 10 shows the correlation between region-averaged JJA DAODs and JJA and ASO GPI. Consistent with the results for the individual large-scale fields and MPI, JJA GPI over the MDR exhibits strong negative correlations ( $\sim-0.7$, also Table 3$)$ with JJA Caribbean DAOD. Similar to MPI, GPI is also directly related to SST via the potential intensity term, so given the negative correlation between DAOD and SST, we would expect a negative correlation between GPI and DAOD. Other terms also comprise the GPI, including vertical wind shear and mid-level moisture, which also correlate negatively with DAOD. The correlation remains statistically significant but is weaker for ASO GPI for most of the MDR. The exception is the east- 

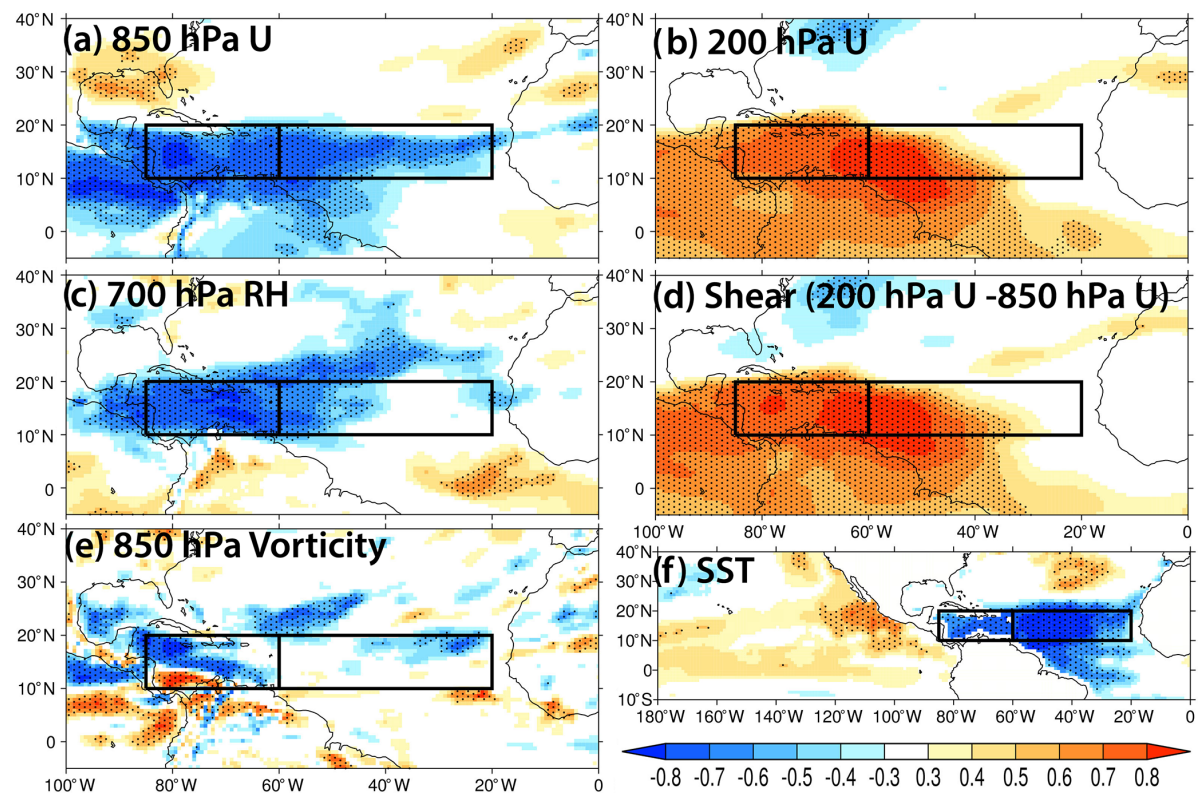

Figure 8. Correlation between MRC JJA regionally averaged DAOD in the Caribbean and JJA (a) $850 \mathrm{hPa} U$, (b) $200 \mathrm{hPa} U$, (c) $700 \mathrm{hPa}$ $\mathrm{RH}$, (d) zonal wind shear, (e) $850 \mathrm{hPa}$ relative vorticity, and (f) SST. Correlations over the black dotted areas are statistically significant.

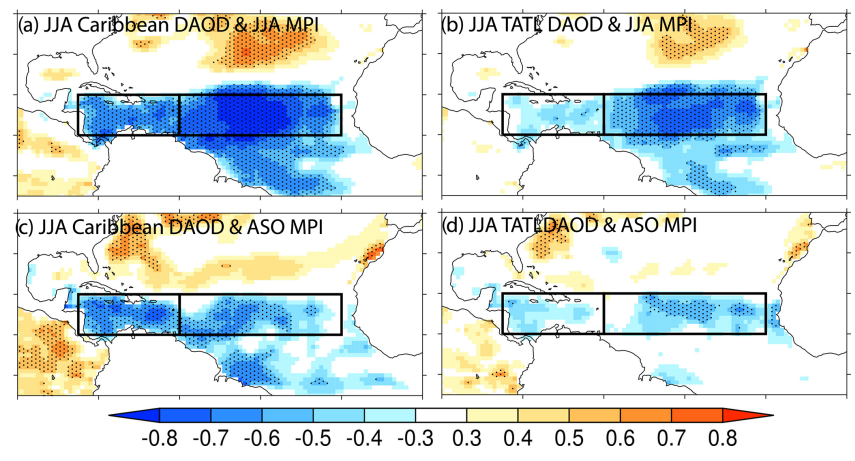

Figure 9. Correlation between (a) MRC JJA regionally averaged DAOD in the Caribbean and JJA maximum potential intensity (MPI), (b) MRC JJA regionally averaged DAOD in the tropical North Atlantic (TATL) and JJA MPI, (c) JJA Caribbean DAOD and ASO MPI, and (d) JJA TATL DAOD and ASO MPI. Correlations over the black dotted areas are statistically significant.

ern tropical North Atlantic, where the negative correlation drops below $95 \%$ statistical significance. The negative correlation of JJA and ASO GPI with JJA tropical North Atlantic region-averaged DAOD is much weaker than that with JJA Caribbean DAOD in the MDR (Fig. 10b and d), which is also consistent with the result for the individual large-scale fields and MPI.

Table 3 summarizes the relationship between large-scale atmosphere/ocean fields, MPI, GPI, and DAOD, with correlations displayed between JJA region-averaged DAOD and concurrent region-averaged fields (i.e., JJA-averaged), as well as the large-scale region-averaged fields during the peak

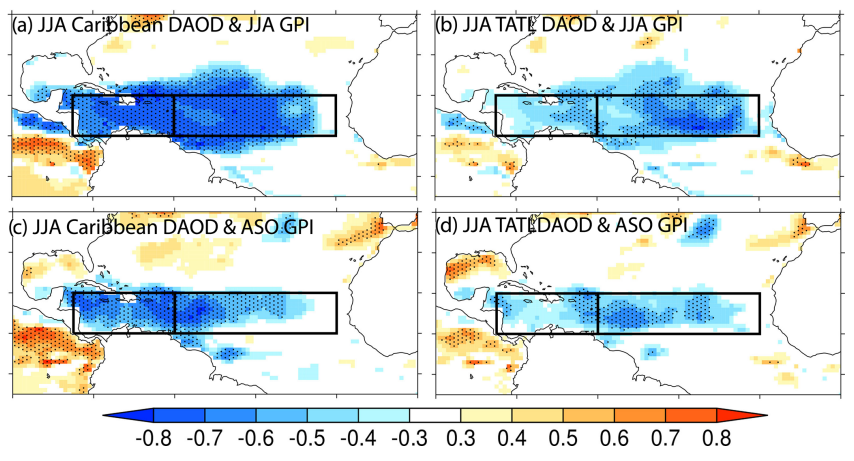

Figure 10. As in Fig. 9 but for the genesis potential index (GPI).

of the Atlantic hurricane season from August-October. The $850 \mathrm{hPa}$ relative vorticity field is excluded as no statistically significant correlations are found. While the correlations between the other five large-scale fields, MPI, GPI, and DAOD tend to weaken from JJA to ASO, the correlations remain significant for all of these large-scale fields, and the integrated TC indices, in the Caribbean during ASO. For the tropical North Atlantic, JJA DAOD has much weaker and insignificant correlations with JJA $200 \mathrm{hPa}$ zonal wind, wind shear, and $700 \mathrm{hPa}$ RH compared to those for the Caribbean. However its negative correlation with SST is as strong as that for the Caribbean in JJA and remains statistically significant from JJA to ASO, although the magnitude of the correlation is weaker in ASO. These contribute to a negative correlation with MPI and GPI and a stronger correlation during JJA than during ASO. 
Table 4. Correlation matrix between JJA and ASO values of $850 \mathrm{hPa} U, 200 \mathrm{hPa} U, 200$ minus $850 \mathrm{hPa} U, 700 \mathrm{hPa} \mathrm{RH}$, and SST over the tropical North Atlantic and the Caribbean, respectively. Correlations that are statistically significant at the $90 \%$ level are highlighted in bold, and those with asterisks are statistically significant at the $95 \%$ level.

\begin{tabular}{lcc}
\hline $\begin{array}{l}\text { Environmental } \\
\text { field }\end{array}$ & $\begin{array}{c}\text { Tropical North } \\
\text { Atlantic }\end{array}$ & Caribbean \\
\hline $850 \mathrm{hPa} U$ & $\mathbf{0 . 5 1}^{*}$ & $\mathbf{0 . 8 4}^{*}$ \\
$200 \mathrm{hPa} U$ & $\mathbf{0 . 7 1}^{*}$ & $\mathbf{0 . 8 8}^{*}$ \\
$200 \mathrm{minus} 850 \mathrm{hPa} U$ & $\mathbf{0 . 7 2}^{*}$ & $\mathbf{0 . 9 0}^{*}$ \\
$700 \mathrm{hPa} \mathrm{RH}$ & $\mathbf{0 . 4 8}^{*}$ & $\mathbf{0 . 7 4}^{*}$ \\
$\mathrm{SST}$ & $\mathbf{0 . 7 7}^{*}$ & $\mathbf{0 . 8 5}^{*}$ \\
\hline
\end{tabular}

Part of the reason for the rapid decrease in the strength of the correlations in the tropical North Atlantic is due to relatively low correlations between JJA and ASO values of large-scale parameters in that portion of the basin, indicating a lack of persistence in atmosphere/ocean conditions when compared with the Caribbean (Table 4). The persistence of the $700 \mathrm{hPa} \mathrm{RH}$ and $850 \mathrm{hPa} U$ fields in the tropical North Atlantic is especially low compared to other fields.

\subsection{Relationship between JJA DAOD and large-scale climate modes}

We next explore the relationship between JJA-averaged DAOD and two large-scale climate modes that have been documented in many studies to impact Atlantic TC activity: ENSO (e.g., Gray, 1984; Goldenberg and Shapiro, 1996; Klotzbach, 2011; Klotzbach et al., 2018) and the AMM (e.g., Kossin and Vimont, 2007; Patricola et al., 2014). El Niño typically reduces Atlantic TC activity through several mechanisms including increasing westerly wind shear especially over the Caribbean (Gray, 1984) and through upper-level tropospheric warming, causing increased static stability and inhibiting deep convection (Tang and Neelin, 2004). The AMM has also been suggested in prior research to significantly impact Atlantic TC activity (Kossin and Vimont, 2007), especially when combined with ENSO (Patricola et al., 2014). A positive phase of the AMM is associated with a warmer-thannormal tropical Atlantic, anomalously low sea level pressure and anomalously weak trade winds - all of which favor Atlantic TC formation (Kossin and Vimont, 2007).

Table 5 displays the correlations between JJA regionally averaged DAODs from the different aerosol reanalysis products and the JJA and ASO ENSO (as represented by the ONI) and AMM indices. There is a positive correlation between JJA Caribbean DAOD and the concurrent (significant at the $90 \%$ level) and ASO ONI (significant at the $95 \%$ level) using MRC and NAAPS-RA, and the correlations with the ONI increase from JJA to ASO. The correlation between (i) JJA tropical North Atlantic DAOD and (ii) JJA and ASO ENSO is not significant, but it is consistent with previous studies (Lau and Kim, 2007; DeFlorio et al., 2016). ENSO events climatologically intensify from boreal summer to boreal autumn (Harrison and Larkin, 1998), which may be part of the reason for the increase in significance of the correlations from JJA to ASO. In addition, this likely also explains part of the reason why Atlantic TC activity correlates more strongly with Caribbean DAOD than with tropical Atlantic DAOD, given the pronounced impact that ENSO has on the Caribbean large-scale environment (Gray, 1984). Figure S3, in which JJA composites of MRC DAOD, $850 \mathrm{hPa}$ horizontal wind, and $700 \mathrm{hPa}$ RH for the three top El Niño and La Niña ENSO years (based on JJA ONI) are shown, corroborates that stronger dust transport into the Caribbean occurs during El Niño years without necessarily strong emissions over Africa and high DAOD over the tropical North Atlantic. We also note that 2015 is both an El Niño and a high-DAOD year, while 2011 is both a La Niña and low-DAOD year. Removing the 2 overlapping years in the composites leads to similar results except that DAOD differences between El Niño and La Niña years are more negative in the tropical North Atlantic, additionally supporting the insignificant correlation between ENSO and tropical North Atlantic DAOD.

The correlations between JJA Caribbean DAOD and JJA AMM are consistently strong and negative $(\sim-0.7)$ with all of the aerosol reanalyses (Table 5). As might be expected given that the signal of the AMM is climatologically strongest in the boreal spring and weakens in the boreal summer and fall (Kossin and Vimont, 2007), correlations of JJA DAOD are weaker with the ASO AMM than with the JJA AMM. Negative correlations are also obtained between the JJA tropical North Atlantic DAOD and the JJA AMM, while the correlation with the ASO AMM is weak and not statistically significant in general. The negative correlations between JJA DAODs and the AMM are consistent with Evan et al.'s (2011) study on the radiative effect of dust aerosols on the AMM. That study showed DAOD to be not only negatively correlated with the AMM but that its variability was found to excite the AMM on interannual to decadal timescales.

So far we have shown that Caribbean DAOD is correlated with Atlantic basin-wide ACE as well as two largescale climate modes: ENSO and the AMM. Both of these modes have been shown to also impact Atlantic TC activity. To remove the influence of these climate indices from the relationship between DAOD and ACE, we use partial correlation analysis (Kleinbaum et al., 2013). Table 6 shows the partial correlation matrix between JJA Caribbean and tropical North Atlantic DAOD and annual Atlantic basin-wide ACE while controlling for the ONI and AMM indices, respectively. Removing the influence of ENSO causes little change in the negative correlation between MRC Caribbean JJA DAOD and ACE. The correlation remains statistically significant, suggesting that ENSO is not primarily responsible for the negative correlation between Caribbean DAOD 
Table 5. Correlations of MRC JJA Caribbean DAOD or JJA tropical North Atlantic (TATL) DAOD with the JJA or ASO Oceanic Niño Index (ONI) and the AMM. Correlations that are statistically significant at the $90 \%$ level are highlighted in bold. Correlations that are statistically significant at the $95 \%$ level are marked with an asterisks.

\begin{tabular}{lrrrr|rrrr}
\hline & \multicolumn{3}{c}{ JJA Caribbean DAOD } & \multicolumn{3}{c}{ JJA TATL DAOD } \\
\cline { 2 - 9 } & CAMSRA & MERRA-2 & NAAPS-RA & MRC & CAMSRA & MERRA-2 & NAAPS-RA & MRC \\
\hline JJA ONI & 0.33 & 0.29 & $\mathbf{0 . 5 0}$ & $\mathbf{0 . 4 4}$ & 0.24 & 0.18 & 0.28 & 0.26 \\
ASO ONI & 0.42 & 0.41 & $\mathbf{0 . 6 1}^{*}$ & $\mathbf{0 . 5 4}$ & 0.38 & 0.30 & 0.42 & 0.41 \\
JJA AMM & $-\mathbf{0 . 7 2}^{*}$ & $-\mathbf{0 . 7 0}^{*}$ & $-\mathbf{0 . 6 3}^{*}$ & $-\mathbf{0 . 7 6}^{*}$ & $-\mathbf{0 . 5 8}^{*}$ & $-\mathbf{0 . 6 5}^{*}$ & -0.36 & $-\mathbf{0 . 6 0}^{*}$ \\
ASO AMM & -0.42 & $-\mathbf{0 . 4 5}$ & -0.30 & $-\mathbf{0 . 4 5}$ & -0.33 & $-\mathbf{0 . 5 2}^{*}$ & 0.01 & -0.33 \\
\hline
\end{tabular}

and Atlantic ACE, at least during the study period. The correlation between tropical North Atlantic JJA DAOD and ACE also changes little, although the correlation is weak and not statistically significant initially. We note that the correlation between ONI and ACE is very weak and is not significant during the 2003-2018 study period, partially due to the extremely active 2004 Atlantic hurricane season which occurred despite a weak El Niño event.

In contrast to the findings of removing ENSO from the DAOD-ACE relationship, after removing the influence of the AMM, the correlation between Caribbean JJA DAOD and Atlantic ACE is much weaker and drops to insignificant levels, suggesting that the AMM is an important factor in the dust-TC relationship. However, it is hard to argue that the AMM is the determining factor in the dust-TC relationship, as the correlation of ACE with JJA Caribbean DAOD is slightly higher than with the JJA AMM (-0.61 vs. 0.59). When the partial correlation is calculated between the AMM and ACE while removing the Caribbean dust (DAOD) influence, the correlation drops from 0.59 to an insignificant level $(r=0.26)$, independent of season examined. This indicates that Caribbean DAOD is, in turn, an important factor in the AMM-TC relationship. When the TATL JJA DAOD is removed, the correlation between AMM and ACE is also reduced, implying that the AMM-DAOD-TC relationship is strongly intertwined. This is physically feasible, as the dust radiative forcing can result in cooler SST, which can introduce anomalously high sea level pressure and stronger trade winds (and therefore stronger vertical wind shear), which is characteristic of a negative AMM. This air-sea coupled response to dust radiative forcing can act over relatively short timescales (e.g., 1 to 2 months) (Evan et al., 2011). Additionally, the dryness of the dusty air and the radiative heating of the dust layer can lead to stronger vertical wind shear and a more stable lower atmosphere, all in line with a negative AMM that creates an environment that is detrimental for TC formation and development. It could be argued that the negative correlation between DAOD and Atlantic TC activity may be a result of forcing of the AMM by African dust.

\section{Sensitivity tests}

The sensitivity of our results to the domain definitions of the tropical North Atlantic and the Caribbean regions is explored by defining equal areas (shifting the separation longitude to $52.5^{\circ} \mathrm{W}$ ) for the two regions within the MDR, as well as by expanding the two regions by $5^{\circ}$ latitude to the north (e.g., to $25^{\circ} \mathrm{N}$ ). Neither of the two new definitions for regions significantly change the correlations between JJA regionally averaged DAOD and large-scale fields (Tables S1, S2). The correlations between the JJA Caribbean DAOD and ACE are $-0.59 /-0.58$ for the longitudinal and latitudinal shift respectively, only slightly lower than -0.61 using the default regional definitions. The correlations between the JJA TATL DAOD and ACE remain insignificant (Table S3).

While airborne dust can impact TC activity, once TCs form and develop, both precipitation and strong winds can significantly remove these dust particles. However, the removal effect by TCs cannot primarily explain the negative DAOD-TC relationship. This is because peak dust activity occurs from June to August, with larger DAOD in June and July than in August over the Atlantic, suggesting that peak DAOD in general leads the peak TC season by $\sim 1-2$ months (Fig. S1). Using June-July average DAOD instead of JuneAugust average DAOD changes our results only slightly. For example, the correlation between June and July Caribbean DAOD and Atlantic ACE is -0.58 , only slightly lower than that using JJA DAOD $(r=-0.61)$ (Table S3). This has implications for using DAOD as an indicator for seasonal TC forecasts, which are often updated in early August.

The sensitivity of the composite analysis of high-JJACaribbean-DAOD years versus low-JJA-Caribbean-DAOD years to the number of years is also explored by using 2 and 4 years for composites in addition to 3 years (Table S4). Consistent results are found across all sensitivity tests. Atlantic basin-wide numbers of tropical depressions, named storms, hurricanes, and major hurricanes, and ACE are higher (by a factor of 1.6-5) in the low-JJA-Caribbean-DAOD seasons than in the high-JJA-Caribbean-DAOD seasons. The ratios of observed average seasonal Atlantic hurricanes and major hurricanes in the low-JJA-Caribbean-DAOD seasons versus the high-JJA-Caribbean-DAOD seasons are generally 
Table 6. Partial correlation matrix between MRC JJA Caribbean and tropical North Atlantic (TATL) DAOD and annual Atlantic basin-wide ACE while controlling for ENSO (using the JJA ONI) and the AMM (using JJA AMM index). Linear correlations (without controlling for the climate modes) between DAOD and ACE, AMM and ENSO indices, and ACE are also listed for comparison purposes. Correlations that are statistically significant at the $90 \%$ level are highlighted in bold, and those with asterisks are statistically significant at the $95 \%$ level. Note that the thresholds for statistical significance are different for partial correlation and linear correlation, as the degrees of freedom are different between the two.

\begin{tabular}{|c|c|c|c|c|c|}
\hline & $\begin{array}{r}\mathrm{ACE} \\
\text { (ctrl. for ENSO) }\end{array}$ & $\begin{array}{r}\mathrm{ACE} \\
\text { (ctrl. for AMM) }\end{array}$ & ACE & $\begin{array}{r}\text { ACE } \\
\text { (ctrl. for Caribbean } \\
\text { DAOD) }\end{array}$ & $\begin{array}{r}\text { ACE } \\
\text { (ctrl. for TATL } \\
\text { DAOD) }\end{array}$ \\
\hline MRC Caribbean DAOD & $-0.62^{*}$ & -0.29 & $-0.61^{*}$ & - & - \\
\hline MRC TATL DAOD & -0.39 & -0.07 & -0.41 & - & - \\
\hline AMM index (JJA and ASO) & - & - & $0.59 * / 0.45$ & $0.26 / 0.26$ & $\mathbf{0 . 4 8} / 0.37$ \\
\hline ONI (JJA and ASO) & - & - & $-0.12 /-0.20$ & $0.20 / 0.18$ & $-0.02 /-0.05$ \\
\hline
\end{tabular}

higher than those for tropical depressions and named storms, suggesting a stronger correlation relationship between dust aerosols and intense storms than weak storms.

\section{Conclusions and discussions}

The relationship between African dust and Atlantic tropical cyclone (TC) activity has been analyzed in many prior studies (e.g., Dunion and Velden, 2004; Evan et al., 2006a; Braun et al., 2013; Pan et al., 2018). This study has revisited this relationship with a statistical analysis using three newly available aerosol reanalyses: the Naval Aerosol Analysis and Prediction System reanalysis (NAAPS-RA), the Modern-Era Retrospective analysis for Research and Applications, Version 2 (MERRA-2) aerosol reanalysis, the Copernicus Atmosphere Monitoring Service reanalysis (CAMSRA), and a multi-reanalysis consensus (MRC) based on the three reanalyses for the period 2003-2018. The datasets are validated with ground-based observations for modal (fine, coarse and total) aerosol optical depth (AOD). The MRC data are primarily used in this study as it generally has better verification results than any of the individual reanalysis products. To our knowledge, this is the first climate study using a multi-reanalysis consensus to represent aerosol conditions. Our findings are summarized below.

1. Total AODs of the three aerosol reanalysis products are similar for the Atlantic Main Development Region; however, AOD attributed to individual aerosol species (such as dust aerosols) can be quite different among the three reanalysis products (Fig. 4). June-July-August (JJA) dust AOD (DAOD) magnitude can differ by as much as 0.06 , corresponding to approximately $60 \%$ of the climatological JJA DAOD based on MRC for the Caribbean, and can differ by as much as 0.05 , approximately $20 \%$ of the climatological JJA DAOD based on MRC for the tropical North Atlantic. This is because total AOD is the only aerosol property constrained by satellite observations through AOD data assimilation in all three aerosol reanalysis products, while speciated AOD is not constrained. This also supports the potential usefulness of MRC, as multi-model consensus values are found to generally be better performers than individual models in aerosol simulations (Sessions et al., 2015; Xian et al., 2019). Despite differences in DAOD magnitude, DAODs of the three reanalysis products correlate significantly over the tropical Atlantic and Caribbean.

2. Each of the three individual reanalyses and the MRC have significant and negative correlations between JJA Caribbean DAOD and seasonal Atlantic accumulated cyclone energy (ACE) (Table 2). High JJA DAOD in the Caribbean is associated with a less conducive environment for hurricane activity as represented by cooler SST, enhanced vertical wind shear, lower mid-level moisture, and by lower maximum potential intensity (MPI) and genesis potential index (GPI) values (Table 3). Pronounced differences in Atlantic TC activity are seen when examining the three seasons with the highest levels of JJA Caribbean DAOD compared with the three seasons with the lowest JJA Caribbean DAOD (Table 4 and Fig. 7). About three times as many major hurricanes occurred during the three lowest-DAOD seasons $(2005,2011,2017)$ compared with the three highest-DAOD seasons $(2018,2015,2014)$. Atlantic TC activity is also negatively correlated with tropical North Atlantic DAOD but not as significantly as with Caribbean DAOD for possible reasons discussed in the conclusion that follows.

3. High Caribbean DAOD is typically associated with El Niño conditions; however ENSO does not appear to significantly impact the Caribbean DAOD-ACE relationship. The robust DAOD-ACE correlation still holds after removing ENSO's influence via partial correlation analysis.

4. JJA North Atlantic DAOD and the Atlantic Meridional Mode (AMM) are intertwined in the dust-TC relation- 
ship. Both the Caribbean and tropical North Atlantic DAODs have strong negative correlations with JJA values of the AMM index (with a stronger correlation for the Caribbean DAOD). Meanwhile, the JJA AMM index correlates significantly with Atlantic ACE. For AMM and DAOD, removing the other in their relationships with ACE dramatically reduces the significance of the correlations based on partial correlation analysis. This result supports Evan et al.'s (2011) work, which showed that African dust excited AMM variability on interannual to decadal timescales through radiative forcing of the underlying SST. Consequently, it can be argued that the negative correlation between Caribbean and tropical North Atlantic DAOD and Atlantic TC activity may be a result of forcing of the AMM by African dust.

These results agree with previous studies that showed negative correlations between boreal summer Atlantic dustiness and TC activity (e.g., Dunion and Velden, 2004; Evan et al., 2006a; Lau and Kim 2007). The correlations obtained in this study, especially those with Caribbean DAOD, are slightly higher than previous studies, including correlations between boreal summer dustiness and ACE (Evan et al., 2006a; Lau and Kim 2007) and between JJA dustiness and ENSO (DeFlorio et al., 2016). We note that the study areas, time periods, and study methods are not identical between our study and these previous studies, implying the usefulness of aerosol reanalyses in climate studies. Various sensitivity tests show that our results are not sensitive to the definitions of areas for the Caribbean and tropical North Atlantic, the number of composite years used, or the definition of the dust season (June-July vs. June-August).

Our results also document statistically significant relationships between Atlantic dustiness and large-scale fields (e.g., SST, vertical wind shear, mid-level moisture, and relative vorticity) and integrated TC diagnostic indices (e.g., MPI and GPI), which can be seen as confounding factors in the dustTC relationship. Exploring the causality of the documented negative correlation between DAOD and Atlantic TC activity through modeling experiments is beyond the scope of this paper. However in some modeling studies, radiative forcing of the scattering dust alone could result in an inverse relationship between African dust and Atlantic TC activity (Strong et al., 2018; Sobel et al., 2019), along with consistent largescale fields associated with TC activity. So it is possible that radiative forcing of the scattering dust is a dominant factor in the inverse dust-TC relationship on seasonal to interannual and basin-wide scales. After all, aerosols are coupled radiatively with meteorology in the ERA-Interim dataset, which provides the large-scale atmospheric data used in this study.

The correlations with Atlantic ACE are higher for Caribbean DAOD than for tropical North Atlantic DAOD a result that was not documented previously. The differences in the relationships of Atlantic ACE with regional DAOD are potentially due to several factors. a. The large-scale environmental fields investigated herein are better self-correlated between the JJA and ASO seasons over the Caribbean than over the tropical North Atlantic (Table 4). Therefore, the higher correlation with JJA Caribbean DAOD, which reflects the large-scale circulation, especially for the low- and mid-level wind flow that modulates how far African dust can be transported, tends to extend into the ASO peak TC season. As was shown in Saunders et al. (2017), the strength of the lowlevel winds in the Caribbean tends to be the most robust diagnostic for seasonal ACE during the peak months of the Atlantic hurricane season.

b. ENSO has a large impact on the Caribbean large-scale environment (Gray, 1984). ENSO-forced SST anomalies typically exhibit very strong persistence from JJA to ASO (Harrison and Larkin, 1998). As Caribbean JJA DAOD is correlated with ENSO to some extent, it is also correlated with Atlantic ACE.

c. There might be a regime shift in the integrated outcome of dust-TC interactions from east to west across the tropical North Atlantic at climate timescales, with the eastern tropical North Atlantic (e.g., close to the African continent) having a positive correlation (e.g., since dust emission is often associated with AEWs emerging from Africa; Jones et al., 2003; Karyampudi and Carlson, 1988), while the correlation becomes more negative heading west across the basin.

d. The relatively larger JJA DAOD variability in the Caribbean (larger relative dynamical range of Caribbean JJA DAOD compared to the tropical north Atlantic JJA DAOD over 2003-2018) could contribute to a higher correlation (Figs. 3 and 4).

e. AOD data quality is comparatively better over the Caribbean than over the tropical North Atlantic (Table 1; Fig. 3), given that AOD reanalyses generally perform better over long-range transport regions than they do closer to the aerosol source regions (Lynch et al., 2016).

The conclusions drawn from this study are based on 16year records (2003-2018) of DAOD data from the MRC. We acknowledge that this analysis represents a relatively short time span for a climate correlation study. Longer-period aerosol reanalyses with good fidelity are needed for further climate studies. These reanalyses face several challenges including dealing with changes to the network of AODobserving satellites over time, as well as reasonable simulations and partitioning of aerosol-speciated AODs associated with rare severe aerosol events (e.g., volcanic eruptions) within AOD data assimilation systems.

It is also worth noting that the 2003-2018 DAOD climatology for the Atlantic MDR could be low relative to the extremely dusty period of the 1980s that has been documented 
by long-term in situ dust concentration measurements made in Barbados (Prospero, 2014) and a 24-year eastern North Atlantic dust cover record derived from the Advanced Very High Resolution Radiometer (Evan et al., 2006a). Dust concentration records at Barbados (1965-2011) and dust cover determined from AVHRR (1982-2005) both indicate that dust levels over the North Atlantic peaked during the mid1980s, when tropical Atlantic TC activity was relatively low (e.g., Wang et al., 2012). Our findings are consistent with the negative correlations reflected in both the earlier dust and the earlier tropical Atlantic TC activity records.

Since we note that June-July Caribbean DAOD are strongly correlated with large-scale atmospheric fields which are frequently used in seasonal hurricane forecasts, DAOD may be a useful confirmation tool for observed thermodynamic conditions. Most groups issuing seasonal hurricane forecasts provide an update in early August (immediately prior to the peak of the Atlantic hurricane season). So early season (June-July) DAOD, especially over the Caribbean, could be a potential indicator for the strength of seasonal Atlantic TC activity. While there is very strong agreement between large-scale zonal wind fields (e.g., the June-Julyaveraged $850 \mathrm{hPa}$ zonal wind over the tropical Atlantic correlates at 0.92 between ERA-Interim and MERRA-2, in which the impact of aerosols on radiation and thereby on meteorology is included), there is less agreement with the midlevel moisture field. The correlation between ERA-Interim and MERRA-2 $700 \mathrm{hPa}$ RH over the tropical Atlantic averaged over June-July is only 0.72 . The DAOD could potentially be used to help clarify the favorability/unfavorability of the thermodynamic environment, as indicated also by the strong correlation between JJA Caribbean DAOD and JJA and ASO MPI.

We believe this study, which shows a robust correlation relationship for the integrated dust-atmosphere-ocean system, could provide a framework to better understand the linkages between DAOD and Atlantic TC activity and how DAOD affects the large-scale environment of the MDR. We find that DAOD in both the tropical Atlantic and Caribbean is negatively correlated with Atlantic hurricane frequency, intensity, and integrated indices such as ACE, with stronger negative correlations in the Caribbean than farther east in the tropical North Atlantic. However, this study focuses on seasonal to interannual timescales and provides analysis from a large-scale point of view. Finer temporal scales (from hours to days) are needed in future studies for cases where African dust is entrained into TC vortices.

Data availability. All data supporting the conclusions of this manuscript are available through the links provided below. AERONET Version 3 Level 2 data: http://aeronet.gsfc.nasa.gov (Giles, 2020). AMM index: https://www.esrl.noaa.gov/psd/ data/timeseries/monthly/AMM/ammsst.data (AMM index, 2020). CAMSRA AOD: https://www.ecmwf.int/en/research/ climate-reanalysis/cams-reanalysis (CAMSRA AOD, 2020). ENSO index: http://origin.cpc.ncep.noaa.gov/products/analysis_ monitoring/ensostuff/ONI_v5.php (NOAA Climate Prediction Center Internet Team, 2020). ERA-Interim monthly means: https://rda.ucar.edu/datasets/ds627.1/ (Stepaniak, 2020). HURDAT2: https://www.aoml.noaa.gov/hrd/hurdat/hurdat2.html (HURDAT2, 2020). MERRA-2 AOD: https://disc.gsfc.nasa.gov/datasets/ M2TMNXAER_V5.12.4/summary?keywords=/MERRA-2/ (MERRA-2 AOD, 2020). NAAPS RA AOD: https://usgodae.org/ /cgi-bin/datalist.pl?dset=nrl_naaps_reanalysis\&summary=Go (NAAPS RA AOD, 2020). NOAA OI SST V2 data: https://www.esrl.noaa.gov/psd/ (NOAA/OAR/ESRL PSL, 2020).

Supplement. The supplement related to this article is available online at: https://doi.org/10.5194/acp-20-15357-2020-supplement.

Author contributions. PJK, JPD, and PX conceived the idea. PX and PJK performed most of the analysis and writing. MAJ calculated and performed the analyses on MPI and GPI. All authors contributed to the writing and revision of the manuscript.

Competing interests. The authors declare that they have no conflict of interest.

Acknowledgements. Philip J. Klotzbach would like to acknowledge a grant from the G. Unger Vetlesen Foundation. Peter R. Colarco is supported by the NASA Modeling, Analysis, and Prediction Program (program manager: David Considine).

Financial support. This research has been supported by the Office of Naval Research (grant no. 75-8478-B-8-5) and the G. Unger Vetlesen Foundation.

Review statement. This paper was edited by Jayanarayanan Kuttippurath and reviewed by two anonymous referees.

\section{References}

AMM index: https://www.esrl.noaa.gov/psd/data/timeseries/ monthly/AMM/ammsst.data, last access: 27 November 2020.

Barnston, A. G., Chelliah, M., and Goldenberg, S. B.: Documentation of a highly ENSO-related SST region in the equatorial Pacific, Atmos. Ocean, 35, 367-383, https://doi.org/10.1080/07055900.1997.9649597, 1997.

Bell, G. D., Halpert, M. S., Schnell, R. C., Higgins, R. W., Lawrimore, J., Kousky, V. E., Tinker, R., Thiaw, W., Chelliah, M., and Artusa, A.: Climate assessment for 1999, B. Am. Meteorol. Soc., 81, S1-S50, https://doi.org/10.1175/15200477(2000)81[s1:CAF]2.0.CO;2, 2000.

Bercos-Hickey, E., Nathan, T. R., and Chen, S. H.: Saharan dust and the African easterly jet-African easterly wave system: Structure, 
location and energetics, Q. J. Roy. Meteor. Soc., 143, 2797-2808, https://doi.org/10.1002/qj.3128, 2017.

Bister, M. and Emanuel, K. A.: Dissipative heating and hurricane intensity, Meteorol. Atmos. Phys., 52, 233-240, 1998.

Bister, M. and Emanuel, K. A.: Low frequency variability of tropical cyclone potential intensity. 1. Interannual to interdecadal variability, J. Geophys. Res., 107, 4801, https://doi.org/10.1029/2001JD000776, 2002.

Braun, S. A.: Re-evaluating the role of the Saharan Air Layer in Atlantic tropical cyclogenesis and evolution, Mon. Weather Rev., 138, 2007-2037, https://doi.org/10.1175/2009MWR3135.1, 2010.

Braun, S. A., Sippel, J. A., Shie, C.-L., and Boller, R. A.: The evolution and role of the Saharan air layer during Hurricane Helene (2006), Mon. Weather Rev., 141, 4269-4295, https://doi.org/10.1175/MWR-D-13-00045.1, 2013.

Bretl, S., Reutter, P., Raible, C. C., Ferrachat, S., Poberaj, C. S., Revell, L. E., and Lohmann, U.: The influence of absorbed solar radiation by Saharan dust on hurricane genesis, J. Geophys. Res.-Atmos., 120, 1902-1917, https://doi.org/10.1002/2014JD022441, 2015.

Buchard, V., Randles. C. A., da Silva, A., Darmenov, A. S., Colarco, P. R., Govindaraju, R. C., Ferrare, R., Hair, J. W., Beyersdorf, A., Ziemba, L. D., and Yu, H.: The MERRA-2 Aerosol Reanalysis, 1980-onward, Part II: Evaluation and case studies, J. Clim., 30, 6851-6872, https://doi.org/10.1175/JCLI-D-16-0613.1, 2017.

Carlson, T. N. and Prospero, J. M.: The large-scale movement of Saharan air outbreaks over the northern equatorial Atlantic, J. Appl. Meteorol., 11, 283-297, https://doi.org/10.1175/15200450(1972)011<0283:TLSMOS>2.0.CO;2, 1972.

Camargo, S. J., Emanuel, K. A., and Sobel, A. H.: Use of a genesis potential index to diagnose ENSO effects on tropical cyclone genesis, J. Clim., 20, 4819-4834, 2007.

CAMSRA AOD: https://www.ecmwf.int/en/research/ climate-reanalysis/cams-reanalysis, last access: 27 November 2020 .

Chin, M., Rood, R., Lin, S., Muller J., and Thompson, A.: Atmospheric sulfur cycle simulated in the global model GOCART: Model description and global properties, J. Geophys. Res.-Atmos., 105, 24671-24687, https://doi.org/10.1029/2000JD900384, 2000.

Colarco, P. R., Toon, O. B., Reid, J. S., Livingston, J. M., Russell, P. B., Redemann, J., Schmid, B., Maring, H. B., Savoie, D., Welton, E. J., Campbell, J. R., Holben, B. N., and Levy, R.: Saharan dust transport to the Caribbean during PRIDE: 2. Transport, vertical profiles, and deposition in simulations of in situ and remote sensing observations, J. Geophys. Res.-Atmos., 108, 8590, https://doi.org/10.1029/2002JD002659, 2003.

Colarco, P., da Silva, A., Chin, M., and Diehl, T.: Online simulations of global aerosol distributions in the NASA GEOS-4 model and comparisons to satellite and ground-based aerosol optical depth, J. Geophys. Res.-Atmos., 115, D1420, https://doi.org/10.1029/2009JD012820, 2010.

Dee, D. P., Uppala, S. M., Simmons, A. J., Berrisford, P., Poli, P., Kobayashi, S., Andrae, U., Alonso-Balmaseda, M., Balsamo, G., Bauer, P., Bechtold, P., Beljaars, A., van de Berg, L., Bidlot, J.-R., Bormann, N., Delsol, C., Dragani, R., Fuentes, M., Geer, A. J., Haimberger, L., Healy, S., Hersbach, H., Hólm, E. V., Isaksen, L., Kållberg, P. W., Köhler, M., Matricardi, M.,
McNally, A., Monge-Sanz, B. M., Morcrette, J.-J., Peubey, C., de Rosnay, P., Tavolato, C., Thépaut, J.-N., and Vitart, F.: The ERA-Interim reanalysis: configuration and performance of the data assimilation system, Q. J. Roy. Meteor. Soc., 137, 553-597, https://doi.org/10.1002/qj.828, 2011.

DeFlorio, M. J., Goodwin, I. D., Cayan, D. R., Miller, A. J., Ghan, S. J., Pierce, D. W., Russell, L. M., and Singh, B.: Interannual modulation of subtropical Atlantic boreal summer dust variability by ENSO, Clim. Dynam., 46, 585-599, https://doi.org/10.1007/s00382-015-2600-7, 2016.

DeMott, P., Sassen, K., Poellot, M., Baumgardner, D., Rogers, D., Brooks, S. D., Prenni, A. J., and Kreidenweis, S. M.: African dust aerosols as atmospheric ice nuclei, Geophys. Res. Lett., 30, 1732, https://doi.org/10.1029/2003GL017410, 2003.

Doherty, O. M., Riemer, N., and Hameed, S.: Saharan mineral dust transport into the Caribbean: Observed atmospheric controls and trends, J. Geophys. Res.-Atmos., 113, D07211, https://doi.org/10.1029/2007JD009171, 2008.

Dunion, J. P.: Re-writing the climatology of the tropical North Atlantic and Caribbean Sea atmosphere, J. Clim., 24, 893-908, https://doi.org/10.1175/2010JCLI3496.1, 2011.

Dunion, J. P. and Marron, C. S.: A reexamination of the Jordan mean tropical sounding based on awareness of the Saharan air layer: Results from 2002, J. Clim., 21, 5242-5253, https://doi.org/10.1175/2008JCLI1868.1, 2008.

Dunion, J. P. and Velden, C. S.: The impact of the Saharan Air Layer on Atlantic tropical cyclone activity, B. Am. Meteorol. Soc., 85, 353-365, https://doi.org/10.1175/BAMS-85-3-353, 2004.

Emanuel, K. A. and Nolan, D. S.: 2004 Tropical cyclone activity and global climate, in: Proc. of 26th Conference on Hurricanes and Tropical Meteorology, American Meteorological Society, Miami, Forida, 240-241 pp. 2004.

Engelstaedter, S. and Washington, R.: Atmospheric controls on the annual cycle of North African dust, J. Geophys. Res.-Atmos., 112, D03103, https://doi.org/10.1029/2006JD007195, 2007.

NOAA Climate Prediction Center Internet Team: ENSO index, http://origin.cpc.ncep.noaa.gov/products/analysis_monitoring/ ensostuff/ONI_v5.php, last access: 27 November 2020.

ERA-Interim monthly means: https://rda.ucar.edu/datasets/ds627.1/. Curator: Dave Stepaniak. Last Access: Nov., 27, 2020.

Evan, A. T., Dunion, J. P., Foley, J. A., Heidinger, A. K., and Velden, C. S.: New evidence for a relationship between Atlantic tropical cyclone activity and African dust outbreaks, Geophys. Res. Lett., 33, L19813, https://doi.org/10.1029/2006GL026408, 2006a.

Evan, A. T., Heidinger, A. K., and Knippertz, P.: Analysis of winter dust activity off the coast of West Africa using a new 24year over-water advanced very high resolution radiometer satellite dust climatology, J. Geophys. Res.-Atmos., 111, D12210, https://doi.org/10.1029/2005JD006336, 2006b.

Evan, A. T., Vimont, D. J., Heidinger, A. K., Kossin, J. P., and Bennartz, R.: The role of aerosols in the evolution of tropical North Atlantic Ocean temperature anomalies, Science, 324, 778-781, https://doi.org/10.1126/science.1167404, 2009.

Evan, A. T., Foltz, G. R., Zhang, D., and Vimont, D. J.: Influence of African dust on ocean-atmosphere variability in the tropical Atlantic, Nat. Geosci., 4, 762-765, https://doi.org/10.1038/ngeo1276, 2011.

Flemming, J., Benedetti, A., Inness, A., Engelen, R. J., Jones, L., Huijnen, V., Remy, S., Parrington, M., Suttie, M., Bozzo, 
A., Peuch, V.-H., Akritidis, D., and Katragkou, E.: The CAMS interim Reanalysis of Carbon Monoxide, Ozone and Aerosol for 2003-2015, Atmos. Chem. Phys., 17, 1945-1983, https://doi.org/10.5194/acp-17-1945-2017, 2017.

Giles, D. M.: AERONET Version 3 Level 2 data, http://aeronet.gsfc. nasa.gov, last access: 27 November 2020.

Giles, D. M., Sinyuk, A., Sorokin, M. G., Schafer, J. S., Smirnov, A., Slutsker, I., Eck, T. F., Holben, B. N., Lewis, J. R., Campbell, J. R., Welton, E. J., Korkin, S. V., and Lyapustin, A. I.: Advancements in the Aerosol Robotic Network (AERONET) Version 3 database - automated near-real-time quality control algorithm with improved cloud screening for Sun photometer aerosol optical depth (AOD) measurements, Atmos. Meas. Tech., 12, 169209, https://doi.org/10.5194/amt-12-169-2019, 2019.

Goldenberg, S. B., Landsea, C. W., Mestas-Nuñez, A. M., and Gray, W. M.: The recent increase in Atlantic hurricane activity: Causes and implications, Science, 293, 474-479, https://doi.org/10.1126/science.1060040, 2001.

Goldenberg, S. B. and Shapiro, L. J.: Physical mechanisms for the association of El Niño and West African rainfall with Atlantic major hurricane activity, J. Clim., 9, 1169-1187, 1996.

Gray, W. M.: Global view of the origin of tropical disturbances and storms, Mon. Weather Rev., 96, 669-700, https://doi.org/10.1175/15200493(1968)096<0669:GVOTOO>2.0.CO;2, 1968.

Gray, W. M.: Atlantic seasonal hurricane frequency. Part I: El Niño and $30 \mathrm{mb}$ quasi-biennial oscillation influences, Mon. Weather Rev., 112, 1649-1668, https://doi.org/10.1175/15200493(1984)112<1649:ASHFPI>2.0.CO;2, 1984.

Grogan, D. F. P., Nathan, T. R., and Chen, S. H.: Effects of Saharan dust on the linear dynamics of African easterly waves, J. Atmos. Sci., 73, 891-911, https://doi.org/10.1175/JAS-D-150143.1, 2016.

Grogan, D. F. P., Nathan, T. R., and Chen, S. H.: Saharan dust and the nonlinear evolution of the African easterly jetAfrican easterly wave system, J. Atmos. Sci., 74, 27-47, https://doi.org/10.1175/JAS-D-16-0118.1, 2017.

Harrison, D. E. and Larkin, N. K.: El Niño-Southern Oscillation sea surface temperature and wind anomalies, 1946-1993, Rev. Geophys., 36, 353-400, https://doi.org/10.1029/98RG00715, 1998.

Herbener, S. R., van den Heever, S. C., Carrio, G. G., Saleeby, S. M., and Cotton W. R.: Aerosol indirect effect on idealized tropical cyclone dynamics, J. Atmos. Sci., 71, 2040-2055, https://doi.org/10.1175/JAS-D-13-0202.1, 2014.

Herbener, S. R., Saleeby, S. M., van den Heever, S. C., and Twohy, C. H.: Tropical storm redistribution of Saharan dust to the upper troposphere and ocean surface, Geophys. Res. Lett., 43, https://doi.org/10.1002/2016GL070262, 2016.

Holben, B. N., Eck, T. F., Slutsker, I., Tanre, D., Buis, J. P., Setzer, A., Vermote, E., Reagan, J. A., Kaufman, Y. J., Nakajima, T., Lavenu, F., Jankowiak, I., and Smirnov, A.: AERONET - A federated instrument network and data archive for aerosol characterization, Remote Sens. Environ., 66, 1-16, https://doi.org/10.1016/S0034-4257(98)00031-5, 1998.

Holben, B. N., Tanré, D., Smirnov, A., Eck, T. F., Slutsker, I., Abuhassan, N., Newcomb, W. W., Schafer, J. S., Chatenet, B., Lavenu, F., Kaufman, Y. J., Castle, J. V., Setzer, A., Markham, B., Clark, D., Frouin, R., Halthore, R., Karneli, A., O’Neill, N. T., Pietras, C., Pinker, R. T., Voss, K., and Zibordi, G.: An emerg- ing ground-based aerosol climatology: Aerosol optical depth from AERONET, J. Geophys. Res.-Atmos., 106, 12067-12097, https://doi.org/10.1029/2001JD900014, 2001.

Holland, G. J.: The maximum potential intensity of tropical cyclones, J. Atmos. Sci. 54, 2519-2541, https://doi.org/10.1175/15200469(1997)054<2519:TMPIOT>2.0.CO;2, 1997.

Hsu, N. C., Gautam, R., Sayer, A. M., Bettenhausen, C., Li, C., Jeong, M. J., Tsay, S.-C., and Holben, B. N.: Global and regional trends of aerosol optical depth over land and ocean using SeaWiFS measurements from 1997 to 2010, Atmos. Chem. Phys., 12, 8037-8053, https://doi.org/10.5194/acp-12-8037-2012, 2012.

HURDAT2: https://www.aoml.noaa.gov/hrd/hurdat/hurdat2.html, last access: 27 November 2020

Hyer, E. J., Reid, J. S., and Zhang, J.: An over-land aerosol optical depth data set for data assimilation by filtering, correction, and aggregation of MODIS Collection 5 optical depth retrievals, Atmos. Meas. Tech., 4, 379-408, https://doi.org/10.5194/amt-4379-2011, 2011.

Inness, A., Baier, F., Benedetti, A., Bouarar, I., Chabrillat, S., Clark, H., Clerbaux, C., Coheur, P., Engelen, R. J., Errera, Q., Flemming, J., George, M., Granier, C., Hadji-Lazaro, J., Huijnen, V., Hurtmans, D., Jones, L., Kaiser, J. W., Kapsomenakis, J., Lefever, K., Leitão, J., Razinger, M., Richter, A., Schultz, M. G., Simmons, A. J., Suttie, M., Stein, O., Thépaut, J.-N., Thouret, V., Vrekoussis, M., Zerefos, C., and the MACC team: The MACC reanalysis: an $8 \mathrm{yr}$ data set of atmospheric composition, Atmos. Chem. Phys., 13, 4073-4109, https://doi.org/10.5194/acp13-4073-2013, 2013.

Inness, A., Ades, M., Agustí-Panareda, A., Barré, J., Benedictow, A., Blechschmidt, A.-M., Dominguez, J. J., Engelen, R., Eskes, H., Flemming, J., Huijnen, V., Jones, L., Kipling, Z., Massart, S., Parrington, M., Peuch, V.-H., Razinger, M., Remy, S., Schulz, M., and Suttie, M.: The CAMS reanalysis of atmospheric composition, Atmos. Chem. Phys., 19, 3515-3556, https://doi.org/10.5194/acp-19-3515-2019, 2019.

Jenkins, G. S., Pratt, A. S., and Heymsfield, A.: Possible linkages between Saharan dust and tropical cyclone rain band invigoration in the eastern Atlantic during NAMMA-06, Geophys. Res. Lett., 35, L08815, https://doi.org/10.1029/2008GL034072, 2008.

Jones, T. A., Cecil, D. J., and Dunion, J.: The environmental and inner-core conditions governing the intensity of Hurricane Erin (2001). Weather Forecast., 22, 708-725, https://doi.org/10.1175/WAF1017.1, 2007.

Jones, C., Mahowald, N. M., and Luo, C. : The role of easterly waves on African desert dust transport, J. Clim., 16, 3617-3628, 2003.

Jones, C., Mahowald, N. M., and Luo, C.: Observational evidence of African desert dust intensification of easterly waves, Geophys. Res. Lett., 31, L17208, https://doi.org/10.1029/2004GL020107, 2004.

Joyce, R. J., Janowiak, J. E., Arkin, P. A., and Xie, P.: CMORPH: A method that produces global precipitation estimates from passive microwave and infrared data at high spatial and temporal resolution, J. Hydrometeorol., 5, 487-503, https://doi.org/10.1175/15257541(2004)005<0487:CAMTPG>2.0.CO;2, 2004. 
Kahn, R. A. and Gaitley, B. J.: An analysis of global aerosol type as retrieved by MISR, J. Geophys. Res.-Atmos., 120, 4248-4281, https://doi.org/10.1002/2015JD023322, 2015.

Kaku, K. C., Reid, J. S., O’Neill, N. T., Quinn, P. K., Coffman, D. J., and Eck, T. F.: Verification and application of the extended spectral deconvolution algorithm (SDA+) methodology to estimate aerosol fine and coarse mode extinction coefficients in the marine boundary layer, Atmos. Meas. Tech., 7, 3399-3412, https://doi.org/10.5194/amt-7-3399-2014, 2014.

Karyampudi, V. M. and Carlson, T. N.: Analysis and numerical simulations of the Saharan air layer and its effect on easterly wave disturbances, J. Atmos. Sci., 45, 3102-3136, https://doi.org/10.1175/15200469(1988)045<3102:AANSOT>2.0.CO;2, 1988.

Karyampudi, V. M. and Pierce, H. F.: Synoptic-scale influence of the Saharan Air Layer on tropical cyclogenesis over the eastern Atlantic, Mont. Weather Rev., 130, 3100-3128, 2002.

Karydis, V. A., Kumar, P., Barahona, D., Sokolik, I. N., and Nenes, A.: On the effect of dust particles on global cloud condensation nuclei and cloud droplet number, J. Geophys. Res.-Atmos., 116, D23204, https://doi.org/10.1029/2011JD016283, 2011.

Khain, A. P.: Notes on state-of-the-art investigations of aerosol effects on precipitation: a critical review, Environ. Res. Lett., 4, 015004, https://doi.org/10.1088/1748-9326/4/1/015004, 2009.

Kleinbaum, D. G., Kupper, L. L., Nizam, A., and Rosenberg, E. S.: Applied Regression Analysis and Other Multivariable Methods, 5th Edn., Cengage Learning Publication, Boston, USA, 2013.

Klotzbach, P. J.: El Niño - Southern Oscillation's impact on Atlantic basin hurricanes and U.S. landfalls, J. Clim., 24, 12521263, https://doi.org/10.1175/2010JCLI3799.1, 2011.

Klotzbach, P. J., Bowen, S. G., Pielke Jr., R., and Bell, M. M.: Continental United States landfall frequency and associated damage, Observations and future risks, B. Am. Meteorol. Soc., 99, 13591376, https://doi.org/10.1175/BAMS-D-17-0184.1, 2018.

Knippertz, P. and Todd, M. C.: The central west Saharan dust hot spot and its relation to African easterly waves and extratropical disturbances, J. Geophys. Res.-Atmos., 115, D12117, https://doi.org/10.1029/2009JD012819, 2010.

Kossin, J. P. and Vimont, D. J.: A more general framework for understanding Atlantic hurricane variability and trends, B. Am. Meteorol. Soc., 88, 1767-1782, https://doi.org/10.1175/BAMS-8811-1767, 2007.

Kuciauskas, A. P., Xian, P., Hyer, E. J., Oyola, M. I., and Campbell, J. R.: Supporting weather forecasters in predicting and monitoring Saharan Air Layer dust events as they impact the Greater Caribbean, B. Am. Meteorol. Soc., 99, 259-268, https://doi.org/10.1175/BAMS-D-16-0212.1, 2018.

Landsea, C. W.: A climatology of intense (or major) Atlantic hurricanes, Mon. Weather Rev., 121, 1703-1713, https://doi.org/10.1175/15200493(1993)121<1703:ACOIMA>2.0.CO;2, 1993.

Landsea, C. W. and Franklin, J. L.: Atlantic hurricane database uncertainty and presentation of a new database format, Mon. Weather Rev., 141, 3576-3592, https://doi.org/10.1175/MWRD-12-00254.1, 2013.

Lau, W. K. M. and Kim, K.: How nature foiled the 2006 hurricane forecasts, Eos Transactions American Geophysical Union, 88, 105-107, https://doi.org/10.1029/2007EO090002, 2007.
Levy, R. C., Remer, L. A., Martins, J. V., Kaufman, Y. J., Plana- Fattori, A., Redemann, J., and Wenny, B.: Evaluation of the MODIS aerosol retrievals over ocean and land during CLAMS, J. Atmos. Sci., 62, 974-992, 2005.

Levy, R. C., Remer, L. A., Kleidman, R. G., Mattoo, S., Ichoku, C., Kahn, R., and Eck, T. F.: Global evaluation of the Collection 5 MODIS dark-target aerosol products over land, Atmos. Chem. Phys., 10, 10399-10420, https://doi.org/10.5194/acp-10-103992010, 2010.

Lynch, P., Reid, J. S., Westphal, D. L., Zhang, J., Hogan, T. F., Hyer, E. J., Curtis, C. A., Hegg, D. A., Shi, Y., Campbell, J. R., Rubin, J. I., Sessions, W. R., Turk, F. J., and Walker, A. L.: An 11-year global gridded aerosol optical thickness reanalysis (v1.0) for atmospheric and climate sciences, Geosci. Model Dev., 9, 14891522, https://doi.org/10.5194/gmd-9-1489-2016, 2016.

Ma, P. L., Zhang, K, Shi, J. J., Matsui, T., and Arking, A.: Direct radiative effect of mineral dust on the development of African easterly waves in late summer, 2003-07, J. Appl. Meteorol. Clim., 51, 2090-2104, https://doi.org/10.1175/JAMC-D11-0215.1, 2012.

MERRA-2 AOD: https://disc.gsfc.nasa.gov/datasets/ M2TMNXAER_5.12.4/summary, last access: 27 November 2020 .

Miller, R. L. and Tegen, I.: Climate response to soil dust aerosols. J. Clim., 11, 3247-3267, https://doi.org/10.1175/15200442(1998)011<3247:CRTSDA>2.0.CO;2, 1998.

NAAPS RA AOD: https://usgodae.org//cgi-bin/datalist.pl?dset= nrl_naaps_reanalysis\&summary=Go, Last access: Nov. 27, 2020.

NOAA/OAR/ESRL PSL: NOAA OI SST V2 data, https:// psl.noaa.gov/data/gridded/data.noaa.oisst.v2.html, Boulder, Colorado, USA, last access: 27 November 2020.

Nathan, T. R., Grogan, D. F. P, and Chen, S. H.: Subcritical destabilization of African easterly waves by Saharan mineral dust, J. Atmos. Sci., 74, 1039-1055, https://doi.org/10.1175/JAS-D-160247.1, 2017.

Nowottnick, E. P., Colarco, P. R., Braun, S. A., Barahona, D. O., da Silva, A., Hlavka, D. L., McGill, M. J., and Spackman J. R.: Dust impacts on the 2012 Hurricane Nadine track during the NASA HS3 field campaign, J. Atmos. Sci., 75, 2473-2489, https://doi.org/10.1175/JAS-D-17-0237.1, 2018.

Nowottnick, E., Colarco, P., da Silva, A., Hlavka, D., and McGill, M.: The fate of saharan dust across the atlantic and implications for a central american dust barrier, Atmos. Chem. Phys., 11, 8415-8431, https://doi.org/10.5194/acp-11-8415-2011, 2011.

O'Neill, N. T., Eck, T. F., Smirnov, A., Holben, B. N., and Thulasiraman, S.: Spectral discrimination of coarse and fine mode optical depth, J. Geophys. Res.-Atmos., 108, 4559, https://doi.org/10.1029/2002JD002975, 2003.

Pan, B., Wang, Y., Hu, J., Lin, Y., Hsieh, J.-S., Logan, T., Feng, X., Jiang J. H., Yung, Y. L., and Zhang, R.: Impacts of Saharan dust on Atlantic regional climate and implications for tropical cyclones, J. Clim., 31, 7621-744, https://doi.org/10.1175/JCLID-16-0776.1, 2018.

Patricola, C. M., Saravanan, R., and Chang, P.: The impact of the El Niño-Southern Oscillation and Atlantic Meridional Mode on seasonal Atlantic tropical cyclone activity, J. Clim., 27, 53115328, https://doi.org/10.1175/JCLI-D-13-00687.1, 2014. 
Pratt, A. S. and Evans, J. L.: Potential impacts of the Saharan Air Layer on numerical model forecasts of North Atlantic tropical cyclogenesis, Weather Forecast., 24, 420-435, https://doi.org/10.1175/2008WAF2007090.1, 2008.

Prospero, J. M.: Long-term measurements of the transport of African mineral dust to the southeastern United States: Implications for regional air quality, J. Geophys. Res.-Atmos., 104, 15917-15927, https://doi.org/10.1029/1999JD900072, 1999.

Prospero, J. M.: Characterizing the temporal and spatial variability of African dust over the Atlantic, Past Global Changes Magazine, 22, 68-69, https://doi.org/10.22498/pages.22.2.68, 2014.

Prospero, J. M. and Lamb, P. J.: African droughts and dust transport to the Caribbean: Climate change implications, Science, 302, 1024-1027, https://doi.org/10.1126/science.1089915, 2003.

Prospero, J. M. and Nees, R. T.: Impact of the North African drought and El Niño on mineral dust in the Barbados trade winds, Nature, 320, 735, https://doi.org/10.1038/320735a0, 1986.

Randles, C. A., daSilva, A. M., Buchard, V., Colarco, P. R., Darmenov, A., Govindaraju, R., Smirnov, A., Holben, B., Ferrare, R., Hair, J., Shinozuka, Y., and Flynn, C. J.: The MERRA2 aerosol reanalysis, 1980 onward. Part I: System description and data assimilation evaluation, J. Clim., 30, 6823-6850, https://doi.org/10.1175/JCLI-D-16-0609.1, 2017.

Reale, O., Lau, W. K., Kim, K. M., and Brin, E.: Atlantic tropical cyclogenetic processes during SOP-3 NAMMA in the GEOS-5 global data assimilation and forecast system, J. Atmos. Sci., 66, 3563-3578, https://doi.org/10.1175/2009JAS3123.1, 2009.

Reale, O., Lau, K. M., and da Silva, A.: Impact of interactive aerosol on the African easterly jet in the NASA GEOS5 global forecasting system, Weather Forecast., 26, 504-519, https://doi.org/10.1175/WAF-D-10-05025.1, 2011.

Reed, K. A., Bacmeister, J. T., Huff, J. J. A., Wu, X., Bates, S. C., and Rosenbloom, N. A.: Exploring the impact of dust on North Atlantic hurricanes in a highresolution climate model, Geophys. Res. Lett., 46, 1105-1112, https://doi.org/10.1029/2018GL080642, 2019.

Reid, J. S., Kinney, J. E., Westphal, D. L., Holben, B. N., Welton, E. J., Tsay, S.-C., Eleuterio, D. P., Campbell, J. R., Christopher, S. A., Colarco, P. R., Jonsson, H. H., Livingston, J. M., Maring, H. B, Meier, M. L., Pilewskie, P., Prospero, J. M., Reid, E. A., Remer, L. A., Russell, P. B., Savoie, D. L., Smirnov, A., and Tanré, D.: Analysis of measurements of Saharan dust by airborne and ground-based remote sensing methods during the Puerto Rico Dust Experiment (PRIDE), J. Geophys. Res.-Atmos., 108, 8586, https://doi.org/10.1029/2002JD002493, 2003.

Reynolds, R. W., Rayner, N. A., Smith, T. M., Stokes, D. C., and Wang, W.: An improved in situ and satellite SST analysis for climate, J. Clim., 15, 1609-1625, https://doi.org/10.1175/15200442(2002)015<1609:AIISAS>2.0.CO;2, 2002.

Riemer, N., Doherty, O. M., and Hameed, S.: On the variability of African dust transport across the Atlantic, Geophys. Res. Lett., 33, L13814, https://doi.org/10.1029/2006GL026163, 2006.

Rienecker, M. M., Suarez, M. J., Gelaro, R., Todling, R., Bacmeister, J., Liu, E., Bosilovich, M. G., Schubert, S. D., Takacs, L., Kim, G.-K., Bloom, S., Junye, C., Collins, D., Conaty, A., da Silva, A., Gu, W., Joiner, J., Koster, R. D., Lucchesi, R., Molod, A., Owens, T., Pawson, S., Pegion, P., Redder, C. R., Reichle, R., Robertson, F. R., Ruddick, A. G., Sienkiewicz, M., and Woollen, J.: MERRA: NASA's Modern Era Retrospective Anal- ysis for Research and Applications, J. Clim., 24, 3624-3648, https://doi.org/10.1175/JCLI-D-11-00015.1, 2011.

Rosenfeld, D., Khain, A., Lynn, B., and Woodley, W. L.: Simulation of hurricane response to suppression of warm rain by sub-micron aerosols, Atmos. Chem. Phys., 7, 3411-3424, https://doi.org/10.5194/acp-7-3411-2007, 2007.

Sassen, K., DeMott, P. J., Prospero, J. M., and Poellot, M. R.: Saharan dust storms and indirect aerosol effects on clouds: CRYSTAL-FACE results, Geophys. Res. Lett., 30, 1633, https://doi.org/10.1029/2003GL017371, 2003.

Saunders, M. A., Klotzbach, P. J., and Lea, A. S.: Replicating annual North Atlantic hurricane activity 1878-2012 from environmental variables, J. Geophys. Res.-Atmos., 122, 6284-6297, https://doi.org/10.1002/2017JD026492, 2017.

Saunders, M. A., Klotzbach. P. J., Lea, A. S. R., Schreck, C. J., and Bell, M. M.: Quantifying the probability and causes of the surprisingly active 2018 North Atlantic hurricane season, Earth Space Sci., 7, 1-14, https://doi.org/10.1029/2019EA000852, 2020.

Sessions, W. R., Reid, J. S., Benedetti, A., Colarco, P. R., da Silva, A., Lu, S., Sekiyama, T., Tanaka, T. Y., Baldasano, J. M., Basart, S., Brooks, M. E., Eck, T. F., Iredell, M., Hansen, J. A., Jorba, O. C., Juang, H.-M. H., Lynch, P., Morcrette, J.-J., Moorthi, S., Mulcahy, J., Pradhan, Y., Razinger, M., Sampson, C. B., Wang, J., and Westphal, D. L.: Development towards a global operational aerosol consensus: basic climatological characteristics of the International Cooperative for Aerosol Prediction MultiModel Ensemble (ICAP-MME), Atmos. Chem. Phys., 15, 335362, https://doi.org/10.5194/acp-15-335-2015, 2015.

Shi, Y., Zhang, J., Reid, J. S., Holben, B., Hyer, E. J., and Curtis, C.: An analysis of the collection 5 MODIS over-ocean aerosol optical depth product for its implication in aerosol assimilation, Atmos. Chem. Phys., 11, 557-565, https://doi.org/10.5194/acp11-557-2011, 2011.

Sippel, J. A., Braun, S. A., and Shie, C.-L.: Environmental influences on the strength of Tropical Storm Debby (2006), J. Atmos. Sci., 68, 2557-2581, https://doi.org/10.1175/2011JAS3648.1, 2011.

Stepaniak, D.: ERA-Interim monthly means, https://rda.ucar.edu/ datasets/ds627.1/, last access: 27 November 2020.

Strong, J. D. O., Vecchi, G. A., and Ginoux, P.: The climatological effect of Saharan dust on global tropical cyclones in a fully coupled GCM, J. Geophys. Res.-Atmos., 123, 5538-5559, https://doi.org/10.1029/2017JD027808, 2018.

Sobel, A. H., Camargo, S. J., and Previdi, M.: Aerosol vs. greenhouse gas effects on tropical cyclone potential intensity and the hydrologic cycle, J. Clim., 32, 5511-5527, https://doi.org/10.1175/JCLI-D-18-0357.1, 2019.

Sun, D., Lau, K. M., and Kafatos, M.: Contrasting the 2007 and 2005 hurricane seasons: Evidence of possible impacts of Saharan dry air and dust on tropical cyclone activity in the Atlantic basin, Geophys. Res. Lett., 35, L15405, https://doi.org/10.1029/2008GL034529, 2008.

Tang, B. H. and Neelin, J. D.: ENSO influence on Atlantic hurricanes via tropospheric warming, Geophys. Res. Lett., 31, L24204, https://doi.org/10.1029/2004GL021072, 2004.

Tompkins A. M., Cardinali, C., Morcrette, J. J., and Rodwell, M.: Influence of aerosol climatology on forecasts of 
the African easterly jet, Geophys. Res. Lett., 32, L10801, https://doi.org/10.1029/2004GL022189, 2005.

Tsamalis, C., Chédin, A., Pelon, J., and Capelle, V.: The seasonal vertical distribution of the Saharan Air Layer and its modulation by the wind, Atmos. Chem. Phys., 13, 11235-11257, https://doi.org/10.5194/acp-13-11235-2013, 2013.

Towhy, C. H., Kreidenweis, S. M., Eidhammer, T., Browell, E.V., Heymsfield A. J., Bansemer, A. R., Anderson, B. E., Chen, G., Ismail, S., DeMott, P. J., and Van Den Heever, S. C.: Saharan dust particles nucleate droplets in eastern Atlantic clouds, Geophys. Res. Lett., 36, L01807, https://doi.org/10.1029/2008GL035846, 2009.

Wang, C., Dong, S., Evan, A. T., Foltz, G. R., and Lee, S.: Multidecadal covariability of North Atlantic sea surface temperature, African dust, Sahel rainfall and Atlantic hurricanes, J. Clim., 25, 5404-5415, https://doi.org/10.1175/JCLI-D-11-00413.1, 2012.

Westphal, D. L., Toon, O. B., and Carlson, T. N.: A two-dimensional numerical investigation of the dynamics and microphysics of Saharan dust storms, J. Geophys. Res.-Atmos., 92, 3027-3049, https://doi.org/10.1029/JD092iD03p03027, 1987.

Wilcox, E. M., Lau, K. M., and Kim, K. M.: A northward shift of the North Atlantic Ocean intertropical convergence zone in response to summertime Saharan dust outbreaks, Geophys. Res. Lett., 37, L04804, https://doi.org/10.1029/2009GL041774, 2010.

Xian, P., Reid, J. S., Turk, J. F., Hyer, E. J., and Westphal, D. L.: Impact of modeled versus satellite measured tropical precipitation on regional smoke optical thickness in an aerosol transport model, Geophys. Res. Lett., 36, L16805, https://doi.org/10.1029/2009GL038823, 2009.
Xian, P., Reid, J. S., Hyer, E. J., Sampson, C. R., Rubin, J. I., Ades, M., Asencio, N., Basart, S., Benedetti A., Bhattacharjee, P. Brooks, M. E., Colarco, P. R., Da Silva, A. M., Eck, T. F., Guth, J., Jorba, O., Kouznetsov, R., Kipling, Z., Sofiev, M., Perez Garcia-Pando, C., Pradhan, Y., Tanaka, T., Wang, J., Westphal, D. L., Yumimoto, K., and Zhang, J.: Current State of the global operational aerosol multi-model ensemble: an update from the International Cooperative for Aerosol Prediction (ICAP), Q. J. Roy. Meteor. Soc., 145 (Suppl. 1), 176-209, https://doi.org/10.1002/qj.3497, 2019.

Zhang, J. and Reid, J. S.: MODIS Aerosol Product Analysis for Data Assimilation: Assessment of Level 2 Aerosol Optical Thickness Retrievals, J. Geophys. Res.-Atmos., 111, 22207, https://doi.org/10.1029/2005JD006898, 2006.

Zhang, H., McFarquhar, G. M., Saleeby, S. M., and Cotton, W. R.: Impacts of Saharan dust as CCN on the evolution of an idealized tropical cyclone, Geophys. Res. Lett., 34, L14812, https://doi.org/10.1029/2007GL029876, 2007.

Zhang, H., McFarquhar, G. M., Cotton, W. R., and Deng, Y.: Direct and indirect impacts of Saharan dust acting as cloud condensation nuclei on tropical cyclone eyewall development, Geophys. Res. Lett., 36, L06802, https://doi.org/10.1029/2009GL037276, 2009.

Zhang, J. and Reid, J. S. : MODIS aerosol product analysis for data assimilation: Assessment of over-ocean level 2 aerosol optical thickness retrievals, J. Geophys. Res.-Atmos., 111, D22207, https://doi.org/10.1029/2005JD006898, 2006.

Zhang, J. and Reid, J. S.: A decadal regional and global trend analysis of the aerosol optical depth using a data-assimilation grade over-water MODIS and Level 2 MISR aerosol products, Atmos. Chem. Phys., 10, 10949-10963, https://doi.org/10.5194/acp-1010949-2010, 2010. 